\title{
Loss of Otx2 in the Adult Retina Disrupts Retinal Pigment Epithelium Function, Causing Photoreceptor Degeneration
}

\author{
Michael Housset, ${ }^{1,2,3}$ Alexander Samuel, ${ }^{1,2,3}$ Mohamed Ettaiche, ${ }^{4}$ Alexis Bemelmans, ${ }^{5}$ Francis Béby, ${ }^{6}$ Nathalie Billon, ${ }^{1,2,3}$ \\ and Thomas Lamonerie ${ }^{1,2,3}$ \\ ${ }^{1}$ Institut de Biologie Valrose, University of Nice Sophia Antipolis, UFR Sciences, ${ }^{2}$ CNRS, UMR7277, and ${ }^{3}$ Inserm U1091, Nice F-06108, France, ${ }^{4}$ Institut de \\ Pharmacologie Moléculaire et Cellulaire, CNRS UMR7275, Valbonne F-06560, France, ${ }^{5}$ Institut de Radiobiologie Cellulaire et Moléculaire, Commissariat à \\ l'Energie Atomique, Fontenay-aux-Roses F-92265, France, and 'Department of Ophthalmology, Queen Fabiola Children's University Hospital, 1020 \\ Brussels, Belgium
}

Photoreceptors are specialized neurons of the retina that receive nursing from the adjacent retinal pigment epithelium (RPE). Frequent in the elderly, photoreceptor loss can originate from primary dysfunction of either cell type. Despite intense interest in the etiology of these diseases, early molecular actors of late-onset photoreceptor degeneration remain elusive, mostly because of the lack of dedicated models. Conditional $0 t x 2$ ablation in the adult mouse retina elicits photoreceptor degeneration, providing a new model of late-onset neuronal disease. Here, we use this model to identify the earliest events after $0 t x 2$ ablation. Electroretinography and gene expression analyses suggest a nonautonomous, RPE-dependent origin for photoreceptor degeneration. This is confirmed by RPE-specific ablation of Otx2, which results in similar photoreceptor degeneration. In contrast, constitutive Otx2 expression in RPE cells prevents degeneration of photoreceptors in 0tx2-ablated retinas. We use chromatin immunoprecipitation followed by massive sequencing (ChIP-seq) analysis to identify the molecular network controlled in vivo by $0 t x 2$ in RPE cells. We uncover four RPE-specific functions coordinated by 0 tx 2 that underpin the cognate photoreceptor degeneration. Many direct $0 t x 2$ target genes are associated with human retinopathies, emphasizing the significance of the model. Importantly, we report a secondary genetic response after $0 t x 2$ ablation, which largely precedes apoptosis of photoreceptors, involving inflammation and stress genes. These findings thus provide novel general markers for clinical detection and prevention of neuronal cell death.

\section{Introduction}

In degenerative disorders, brain neurons can succumb to intrinsic failure or to dysfunction of their environment, such as cytokine release by microglia (Zindler and Zipp, 2010). Similarly, photoreceptors may die from autonomous or nonautonomous defects. In the mature retina, outer segments of photoreceptors establish close contact with retinal pigment epithelium (RPE) microvilli (Bramall et al., 2010). RPE cells perform essential functions for photoreceptors, including homeostasis of the microenvironment, protection against light-induced oxidative damage, regeneration of photo-pigment, and phagocytosis of shed discs (Young and Bok, 1969). Defects in any of these functions lead to a progressive loss of photoreceptors (Pacione et al., 2003). How-

Received March 13, 2013; revised April 26, 2013; accepted April 26, 2013.

Author contributions: M.H. and T.L. designed research; M.H., A.S., M.E., F.B., and T.L. performed research; A.B. contributed unpublished reagents/analytic tools; M.H., A.S., M.E., N.B., and T.L. analyzed data; M.H., N.B., and T.L. wrote the paper.

This work was supported by the CNRS and Retina France (T.L.). M.H. was supported by the French Research Ministry (fellowship) and the Fondation Recherche Médicale. We thank Michaël Delhorbe and Cendrine Dubaud for expert handling of mice; Mickael Clarkson for help in ChIP-seq setup; Raivo Kolde for statistical analyses; and Martin Raff, Christian Braendle, and Pierre Godement for comments on the manuscript.

The authors declare no competing financial interests.

Correspondence should be addressed to Dr. Thomas Lamonerie, Institut de Biologie Valrose, University of Nice Sophia Antipolis, UFR Sciences, Nice F-06108, France. E-mail: lamonerie@unice.fr.

DOI:10.1523/JNEUROSCI.1099-13.2013

Copyright $\odot 2013$ the authors $\quad 0270-6474 / 13 / 339890-15 \$ 15.00 / 0$ ever, the molecular links that connect RPE alteration to photoreceptor degeneration remain poorly understood.

The use of animal models that develop retinal diseases with similar traits to humans has enhanced our understanding of inherited retinal deficiencies. However, because most relevant mutations also affect developmental processes, these models generally preclude the assessment of gene function in the mature retina. In general, there is a paucity of suitable models for adult diseases (Fletcher et al., 2011). In particular, very few of the existing models allow the study of the early genetic changes at the root of photoreceptor degeneration. One important regulatory gene that is expressed both in RPE and photoreceptor cells (the major cell types involved in retinal diseases) is Otx2. This gene encodes a key transcription factor for the development of the brain and sensory organs (Acampora et al., 1995; Cantos et al., 2000; Fossat et al., 2006). During retina development, Otx2 regulates RPE specification (Martinez-Morales et al., 2001), and photoreceptor and bipolar cell differentiation and maturation (Nishida et al., 2003; Koike et al., 2007; Sato et al., 2007). Otx2 expression is maintained in these three cell types throughout life (Fossat et al., 2007) and is critical for photoreceptor maintenance (Beby et al., 2010). Otx2 also modulates the plasticity of the visual cortex (Beurdeley et al., 2012). Mutations of this gene in humans have been linked to ocular malformation, pituitary defects, and mental retardation (Gorbenko Del Blanco et al., 2012).

We developed a genetic model that allows conditional Otx2 ablation in mice at any life stage (Fossat et al., 2006). In the adult 
retina, Otx2 ablation leads to dramatic photoreceptor degeneration, starting $20 \mathrm{~d}$ later and ending with their full disappearance within 4 months (Beby et al., 2010). Here, we have used this model to identify the primary cellular and molecular bases of this neuronal degeneration. Using a combination of functional and genomic approaches, we demonstrate a nonautonomous, RPEdependent origin for photoreceptor cell degeneration. We identify two key features of the genetic response to the synchronous ablation of Otx2: (1) immediately after Otx2 ablation, we observe downregulation of genes directly regulated by Otx2, controlling functions essential for RPE homeostasis; and (2) we observe a shifted wave of upregulated genes involved in stress, inflammation, and apoptosis. As these genes are induced well before apoptosis starts, their identification provides new potential markers for clinical screening and prevention of neurodegeneration.

\section{Materials and Methods}

Mouse breeding and tamoxifen administration. Mice were housed with a $12 \mathrm{~h}$ light/dark cycle. All mouse strains were maintained in 129/SV background. Otx $2^{\text {CreERT2/flox }}, \mathrm{Otx} 2^{\text {flox/flox }}$, and $\mathrm{Ot} x 2^{\mathrm{Otx} 2-G F P /+}$ mouse lines were generated as described previously (Fossat et al., 2006, 2007). For Otx2 self-knock-out (sKO), one intraperitoneal injection of tamoxifen (Sigma-Aldrich; $10 \mathrm{mg} / \mathrm{ml}$ in sunflower oil) was done at $1 \mathrm{mg}$ per $20 \mathrm{~g}$ body weight at 3:00 P.M. Mice of either sex were used. Animals were handled according to French regulation, the European Communities Council Directive, as well as the Association for Research in Vision and Ophthalmology Statement for Use of Animals in Ophthalmic and Vision Research. Protocols were approved by CIEPAL-Azur, the local ethic committee for animal experimentation. T.L. received the authorization to experiment \#A06-261 from the Direction Départementale de la Protection des Populations des Alpes-Maritimes, France.

Scotopic electroretinogram recordings. After overnight dark adaptation, mice were anesthetized $(60 \mathrm{mg} / \mathrm{kg}$ pentobarbital, i.p.) under dim red light $(640 \mathrm{~nm})$ and placed on a heating pad to maintain body temperature near $38^{\circ} \mathrm{C}$. Pupils were dilated with $2.5 \%$ neosynephrine and $0.5 \%$ Mydriaticum, and corneas were kept moist with local application of $1 \%$ carboxymethylcellulose sodium (Celluvisc; Allergan). Electroretinogram (ERG) was recorded using an $\mathrm{AgCl}$ ring electrode in contact with the corneal surface through a thin layer of $0.7 \%$ methylcellulose. Needle electrodes placed in the ear served as reference. Animals were grounded with a subcutaneous electrode placed in the neck region. The darkadapted responses (scotopic ERG) were recorded with an ERG test system (UTAS 2000; LKC Technologies), as described previously (Ettaiche et al., 2001). Light stimuli were produced by a Grass PS 22 xenon flash positioned $10 \mathrm{~cm}$ from the eye. Because of anesthesia duration (20 min), ERGs were recorded on both eyes using only a flash intensity of $3.3 \mathrm{log}$ scot td.sec. Responses of 5 successive flashes were averaged, and the interflash interval was $60 \mathrm{~s}$. Responses were differentially amplified (0.3$500 \mathrm{~Hz}$ ), averaged, and stored using a UTAS EM-2000 signal averaging system (LKC Technologies).

The amplitude of the a-wave and the implicit time were measured from the prestimulus baseline to the trough of the a-wave. The b-wave amplitude and the b-wave implicit time were measured from the trough of the a-wave to the positive peak. The amplitude of the c-wave and the implicit time were measured from the prestimulus baseline to the peak of the c-wave.

$R N A$ isolation and $q R T-P C R$. Retinas were dissected at 3:00 P.M. in cold PBS. Total RNA was prepared with TRIzol (Invitrogen). First-strand cDNA was synthesized using $1 \mu \mathrm{g}$ of total mRNA, MLV reverse transcriptase (Promega), and random hexamers. For real-time PCR, 1/100 of cDNA was used per reaction using PowerSYBR Green PCR mix and StepOne Plus apparatus and software (Applied Biosystems). Comparable efficiency of each PCR was first demonstrated using serial dilutions of control cDNA. Gene to TBP ratios were determined from three independent assays by the $2-\Delta \mathrm{C}_{\mathrm{t}}$ method. PCR cycles are as follows: $15 \mathrm{~s}$ at $95^{\circ} \mathrm{C}$, $30 \mathrm{~s}$ at $60^{\circ} \mathrm{C}, 30 \mathrm{~s}$ at $72^{\circ} \mathrm{C}$. Sequence information for primers and amplicon size are available upon request.
Microarray analysis. All microarrays were performed in biological triplicates. RNA processing for microarray was performed by ProfileXpert platform. Quantity and quality of RNA were ensured before labeling by nanodrop (Thermo Scientific) and Bioanalyzer 2100 (Agilent). Samples with an RNA integrity number $>7.0$ were considered suitable for labeling. For samples meeting standards, $1 \mu \mathrm{g}$ of total RNA was labeled using the MessageAmp II Kit (Ambion). A total of $10 \mu \mathrm{g}$ of labeled and fragmented cRNA were then hybridized to CodeLink Mouse Whole Genome Bioarray (GE Healthcare) for $18 \mathrm{~h}$ at $37^{\circ} \mathrm{C}$. Automated washing and staining were performed according to the manufacturer's protocols. Chips were scanned with a high-numerical aperture and flying objective (FOL) lens in the Genepix 4000B scanner (Acon) and GENEPIX software. Raw expression data were analyzed using CODELINK expression software, version 4.0 (GE Healthcare).

Microarray data processing. CODELINK software was used to normalize the raw hybridization signal on each array to the median of the array (median intensity is 1 after normalization) for better cross-array comparison. The threshold of detection was calculated using the normalized signal intensities of the 100 negative control samples in the array. Signal intensities were then converted to log base 2 values. Comparison and filtering were performed using GENESPRING version 7.0 software (Agilent). Gene expression data were analyzed by comparing each time point against all others and time days 0 and 2 against days 4 and 8 using moderated $t$ test from Bioconductor package Limma (Gentleman et al., 2004) with false discovery rate level 0.2 . Genes with a fold change ratio $<1.3$ were filtered out. Cluster analyses of expression data of regulated genes were performed using the TM4 program (Saeed et al., 2006).

Chromatin immunoprecipitation (ChIP). For RPE ChIP, two independent pools of chromatin were prepared: one from wild-type (WT) mice that express normal Otx2 protein and one from Otx2-GFP knock-in mice that express an Otx2-GFP fusion protein. For each pool, 40 mouse eyes were dissected to remove cornea, lens, and retina. RPE/choroid eye cups were directly cross-linked in 1\% formaldehyde in DMEM at room temperature for $10 \mathrm{~min}$ then quenched by adding glycine at a final concentration $125 \mathrm{~mm}$ and incubated at room temperature for $5 \mathrm{~min}$. Eye cups were washed twice in cell wash buffer (20 mM HEPES, pH 7.4, $150 \mathrm{~mm}$ $\mathrm{NaCl}, 125 \mathrm{~mm}$ glycine, $1 \mathrm{~mm}$ PMSF). RPE/choroid nuclei ( $\sim 5$ million) were then isolated with a Dounce (pestle B) in cell lysis buffer $(20 \mathrm{~mm}$ HEPES, pH 7.4, 1 mM EDTA, 150 mm NaCl, 1\% SDS, 125 mm glycine, 1 $\mathrm{mM}$ PMSF). Eye cups were removed and RPE/choroid nuclei suspension was obtained. The ChIP procedures were performed as described at the Farnham Laboratory website (http://farnham.genomecenter.ucdavis. edu/protocol.html). A goat antibody raised against OTX2 (R\&D Systems) and a rabbit antibody raised against GFP (Abcam) were used to specifically precipitate chromatin-Otx2 complexes from WT mice in the WT assay, and chromatin-Otx2-GFP complexes from $O t \times 2^{\text {Otx2-GFP/+ }}$ mice in the Otx2-GFP assay, respectively. A goat antibody raised against Laminin B (Santa Cruz Biotechnology) and the rabbit GFP antibody were applied to WT RPE chromatin and used as controls for WT and Otx2-GFP assays, respectively. The final DNA precipitates were resuspended in $20 \mu$ l of Tris-EDTA (10 mm Tris- $\mathrm{HCl}, \mathrm{pH} 8.0,1$ mm EDTA), and $0.5 \mu \mathrm{l}$ of each sample was used for PCR with primers designed to amplify $300 \mathrm{bp}$ fragments in genomic regions. The relative enrichment of each genomic region was measured as the ratio of the amount PCR sample obtained with a specific assay to that of its respective control. Sequence information for primers and amplicon size are available upon request.

ChIP-seq, clustering of sequence reads, and identification of Otx2 binding regions (OBRs). ChIP-seq experiments were performed according to standard protocols as previously described (Kobi et al., 2010). All four samples of ChIP dual assay were processed for ChIP-seq by IGBMC sequencing platform (IGBMC). Quantity and quality of DNA were ensured before processing by Qubit dsDNA HS Kit (Invitrogen) and Bioanalyzer 2100 (Agilent). For each sample, $10 \mathrm{ng}$ of DNA was used to generate the ChIP-DNA library. Libraries were analyzed by Bioanalyzer 2100 (Agilent) before they were massively sequenced by Illumina GAIIx Sequencer generating 40 million reads of 35 bp length per sample on average. Raw reads data were analyzed and aligned on mouse genome mm 9 by CASAVA version 1.8 . 

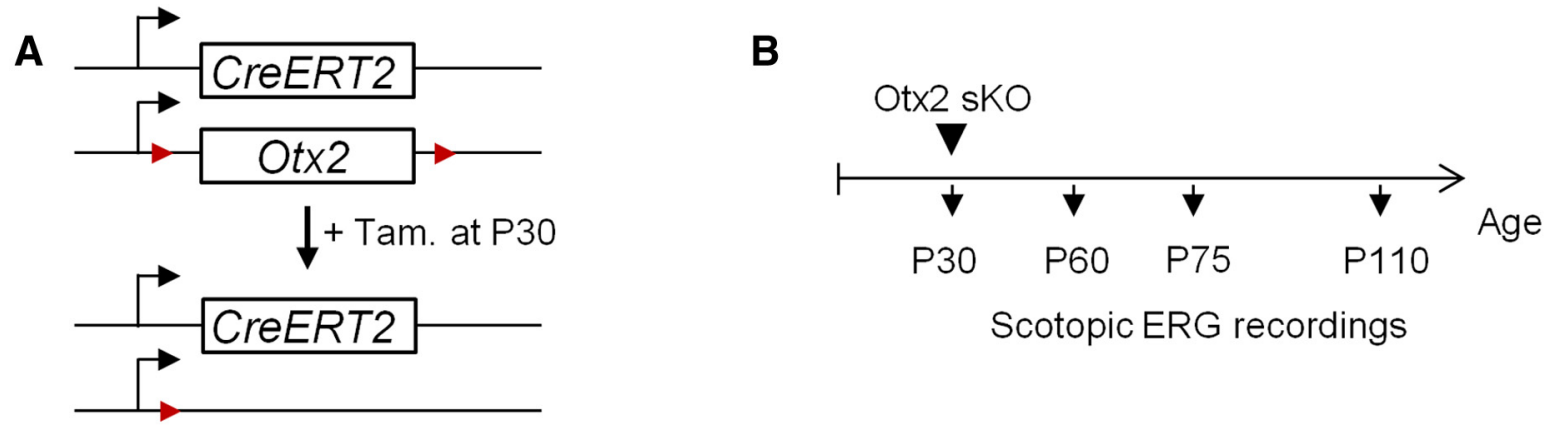

Scotopic ERG recordings

C

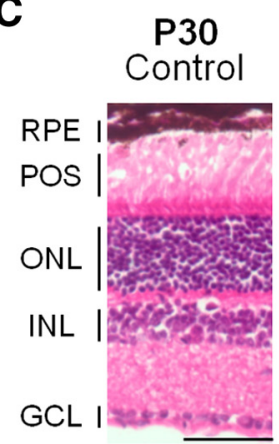

Control

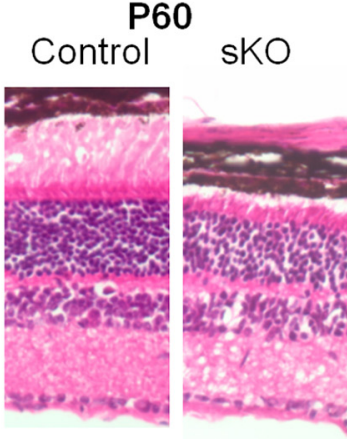

P75

Control sKO

P110

Control sKO
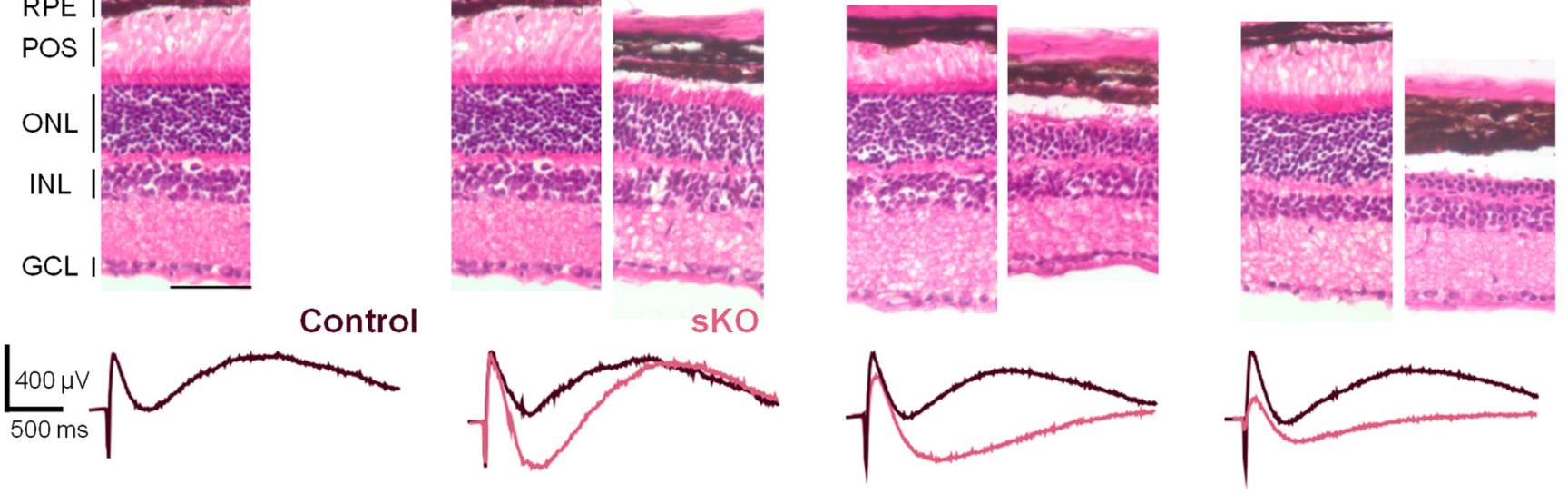

D

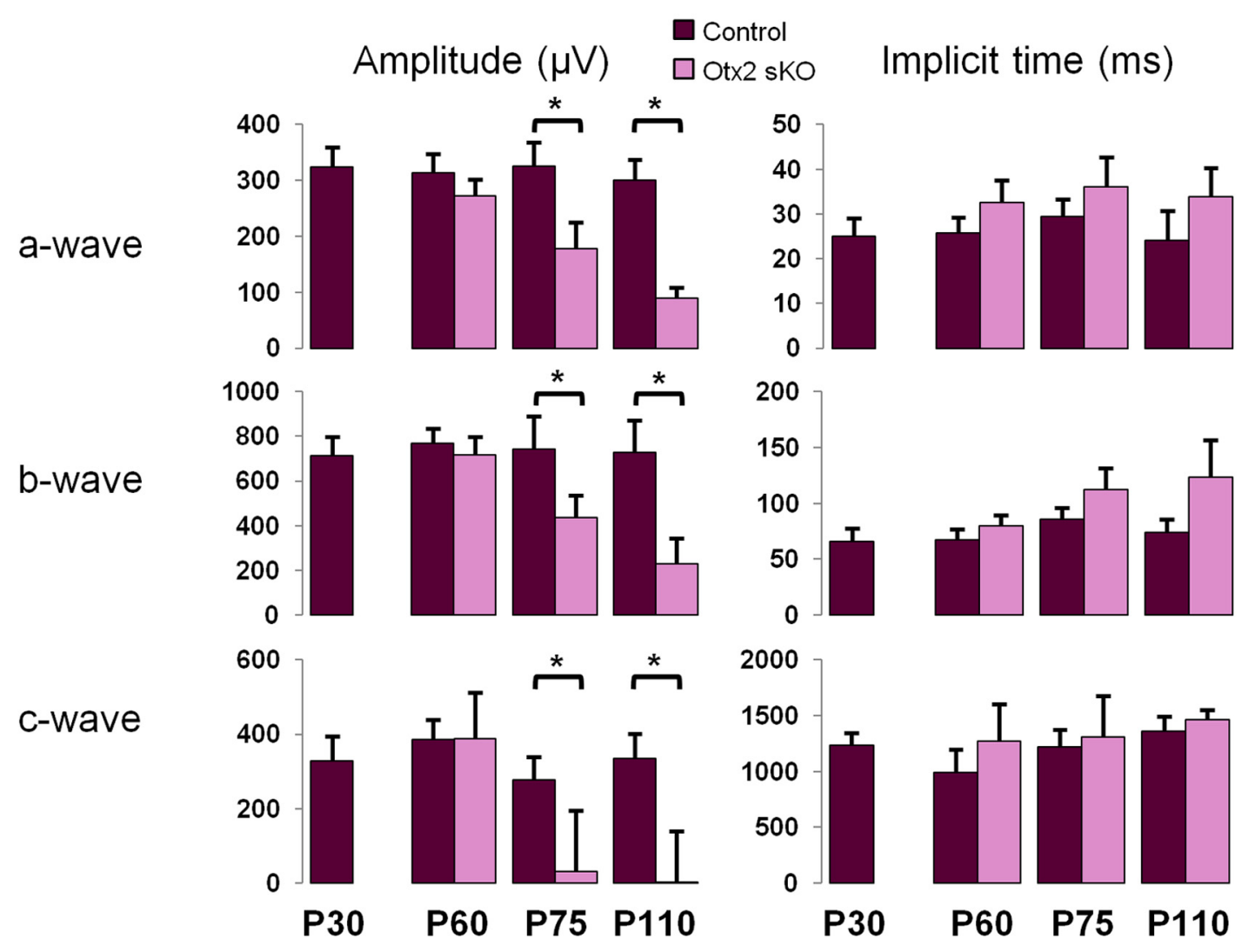

Figure 1. Otx2 sK0 deeply impairs RPE and neural retina activity. $A$, Schematic diagram of Otx2 allele constitution before and after induction of sK0, by tamoxifen injection at P30. Boxes represent coding sequences of each Otx2 allele; black arrows, Otx2 promoters; red triangles, IoxP sites. B, Schematic of the time course for ERG recordings. $\boldsymbol{C}$, Histological and functional (Figure legend continues.) 
Peak detection for WT and Otx2-GFP assays were performed using the MACS software (http://liulab.dfci.harvard.edu/MACS/) (Feng et al., 2012) under settings where the Lmnb-ChIP and GFP-ChIP made on WT RPE were used as negative control, respectively. OBRs sharing at least 50 bp in both assays were considered as common OBRs. Common OBRs were then annotated using PeakAnalyzer version 1.3 free software, with respect to the coordinates of the beginning and end of RefSeq transcripts. Clustering was performed by first generating density (.wig format files) counting the number of tags in a $25 \mathrm{pb}$ sliding window for each ChIP-seq.

The nucleotide sequences for 500 highly occupied loci were extracted from the UCSC genome browser of mouse genome build $\mathrm{mm} 9$ and analyzed for overrepresented sequences by MEME-ChIP software version 4.8 (Machanick and Bailey, 2011).

Construction and production of lentiviral vectors. The lentiviral plasmids used in this study were derived from the control pTrip-PGK-GFP plasmid (Bemelmans et al., 2005). For the Cre-GFP transgene vector, the $1 \mathrm{~kb}$ BglII fragment of pTZCreN plasmid, which includes the Cre cDNA and the nuclear localization signal, was inserted in-frame at the $\mathrm{N}$ terminus of GFP in pTrip-PGK-GFP. For the Otx2-HA transgene, mouse Otx2 cDNA fused in C-terminal to HA-tag was substituted to the GFP ORF in the pTrip-PGK-GFP plasmid using BamHI and BstbI sites. The sequences were verified by sequencing and in vitro functional assays.

Recombinant lentiviral particles were produced by transient transfection of 293T cells as previously described (Kostic et al., 2011). Viral supernatants were concentrated by ultracentrifugation at $70,000 \times g$ for $90 \mathrm{~min}$ at $4^{\circ} \mathrm{C}$. Finally, to achieve a 1000 -fold concentration of the initial supernatant, viral pellets were resuspended in a minimum of volume of PBS containing $10 \mathrm{mg} / \mathrm{ml} \mathrm{BSA}$. Aliquots of 5-10 $\mu \mathrm{l}$ were then stored at $-80^{\circ} \mathrm{C}$. Total particle concentration of the viral stocks was estimated by quantification of the 24 capsid protein using RETRO-TEK HIV-1 p24 Antigen ELISA kit (ZeptoMetrix) according to the manufacturer's instructions.

Subretinal injection. Mice were anesthetized with a mixture of ketamine $(66 \mathrm{mg} / \mathrm{kg})$ and xylazine $(11 \mathrm{mg} / \mathrm{kg})$, and pupils were dilated with 2.5\% neosynephrine and $0.5 \%$ Mydriaticum (Novartis Pharma). Mice were then positioned on a heated platform to maintain body temperature, and corneas were kept moist with local application of $0.9 \% \mathrm{NaCl}$ physiologic serum (bébisol, Omega Pharma). The dorsal cornea was punctured at its periphery with a 30-gauge needle. A 34-gauge blunt needle mounted on a Nanofil syringe (World Precision Instruments) was then inserted into this hole to reach the posterior temporal part of the subretinal space. A total of $3 \mu \mathrm{l}$ of viral suspension containing $40 \mathrm{ng}$ of p 24 was injected at $300 \mathrm{nl} / \mathrm{s}$ to create a subretinal bleb, and the needle was left in place $30 \mathrm{~s}$ before withdrawal. Otx $2^{\text {floxfflox }}$ and WT mice were injected at P30 with Cre-GFP viral suspension, whereas Otx2 $2^{\text {CreERT2/flox }}$ were injected at P25 with Otx2-HA viral suspension. As a control, the contralateral eye was injected with GFP viral suspension.

Immunocytochemistry and histological studies. Eyes were fixed in $4 \%$ paraformaldehyde in PBS for $3 \mathrm{~h}$ at $4^{\circ} \mathrm{C}$, rinsed twice $(30 \mathrm{~min}$ ) in PBS, protected in PBS-sucrose $(10-30 \%)$ and frozen in Tissue-Tek OCT at $-80^{\circ} \mathrm{C}$. Sections $(10 \mu \mathrm{m})$ were mounted onto SuperFrost + slides (Fisher Scientific), blocked $1 \mathrm{~h}$ in PBST (PBS with $0.2 \%$ gelatin and $0.1 \%$ Triton $\mathrm{X}-100)$ containing $5 \%$ donkey serum and incubated overnight at $4^{\circ} \mathrm{C}$ with the primary antibodies diluted in PBST with $2 \%$ donkey serum. After rinsing, slides were incubated $1 \mathrm{~h}$ at $20^{\circ} \mathrm{C}$ with the secondary antibodies. Specimens were washed twice $15 \mathrm{~min}$ in PBS, coverslipped with Vectashield, observed under fluorescent LSM 510 meta microscope (Carl Zeiss), and images analyzed using LSM Image browser software version 4.2 (Carl Zeiss). Primary antibodies were used at the following concen-

\section{$\leftarrow$}

(Figure legend continued.) evolution of adult retina after Otx2 sK0. Top, Hematoxylin and eosin staining of control and sKO retina vertical section at the indicated times. Bottom, Scotopic ERG traces of control (purple) and sKO (red) mice at corresponding times. D, Quantification of averaged amplitude and implicit time of a-, b-, and c-wave in ERG of control and sKO mice at indicated times. Error bars indicate SD. ${ }^{*} p \leq 0.05$, statistically significant change (Student's $t$ test). Tam, Tamoxifen; POS, photoreceptor outer segments; ONL, outer nuclear layer; INL, inner nuclear layer; GCL, ganglion cell layer. Scale bar, $50 \mu \mathrm{m}$. trations: rabbit anti-GFP (1/1000) (Abcam), and goat anti-Otx2 (1/1000) (R\&D Systems). Secondary antibodies (1/1000) included the following: donkey anti-goat AlexaFluor-647 and donkey anti-rabbit AlexaFluor488 (Invitrogen). Hematoxylin and eosin staining was performed according to standard protocol.

Statistical analyses. Gene ontology analyses were performed using the DAVID tool (http://david.abcc.ncifcrf.gov/). Gene enrichment for retinal disease was calculated using Fisher's exact test. $p$ value corresponds to the enrichment of the 71 deregulated genes in a list of 292 retinopathyrelated genes, including RetNet genes and self-curated gene lists (AMD and oculocutaneous genes) on Malacards (www.Malacards.org) compared with mouse whole genome.

\section{Results}

\section{RPE and/or Müller cell activity is first modified in Otx2 sKO retina}

To address the mechanisms of late-onset photoreceptor degeneration, we devised a model coined sKO, which combines a floxed Otx2 allele and an Otx2 allele expressing the tamoxifen-inducible CreERT2 recombinase. We triggered Otx 2 sKO in adult Otx $2^{\text {flox/CreERT2 }}$ mice at postnatal day 30 (P30). Tamoxifen- or vehicle-treated animals are referred to as mutants or controls, respectively (Fig. 1A). Although gene deletion was efficient in all mutant retinal cell types expressing Otx2 (i.e., RPE, photoreceptor, and bipolar cells), it only provoked the death of photoreceptor cells, which underwent apoptosis from 20 d later (Beby et al., 2010). The cause of photoreceptor degeneration might be either autonomous or result from dysfunction of neighboring cells (e.g., RPE) or both. To identify the cellular origin of photoreceptor degeneration, we first performed ERG, which simultaneously records light-induced electric activity of photoreceptor cells (a-wave), bipolar cells (b-wave), and Müller and RPE cells (c-wave). Retinal activity of control and Otx2 mutant mice was measured in scotopic conditions at P30, P60, P75, and P110 (Fig. $1 B)$. At P60, one month after Otx2 ablation, amplitude and implicit time of a-, b-, and c-waves of mutant retinas were not significantly different from control retinas. By contrast, the c-wave exhibited a strong hyperpolarization component in mutants $(-400 \mu \mathrm{V})$, which was absent in controls, suggesting that, at earlier time points, only RPE and/or Müller cells were affected (Fig. 1C). At P75, amplitude of a- and b-wave decreased by $45 \%$ and $41 \%$, respectively, in mutants, whereas depolarization amplitude of c-wave decreased by $89 \%$. The hyperpolarization component of c-wave persisted in mutants (Fig. 1D). Finally, at P110, a-wave was further reduced by $70 \%$ in mutants, reflecting the thinning of photoreceptor layer observed at that time. The b-wave was reduced by $68 \%$ in mutants. The c-wave depolarization was abolished and the hyperpolarization component was very weak.

Together, these results show that deletion of Otx2 in the whole retina dramatically alters the function of RPE and/or Müller cells early on, and over a more extended time period, Otx 2 ablation also affects activity of photoreceptor and bipolar cells. Thus, the latter two cell types exhibited parallel deterioration of their electric activity at a slower pace compared with RPE cells.

\section{Identification of a core set of deregulated genes after Otx2 sKO in the mature retina}

The Otx2 sKO model displays two features that make it particularly interesting for investigating the molecular mechanisms of photoreceptor degeneration: first, gene ablation occurs in $>90 \%$ of cells and Otx2 protein completely disappears $4 \mathrm{~d}$ after Otx2 sKO (Beby et al., 2010). Second, there is an asymptomatic period of $10 \mathrm{~d}$, during which primary molecular changes accounting for subsequent photoreceptor degeneration may take place. We took advantage of these two features in time-series experiments of 
A Otx2 sKo at P30
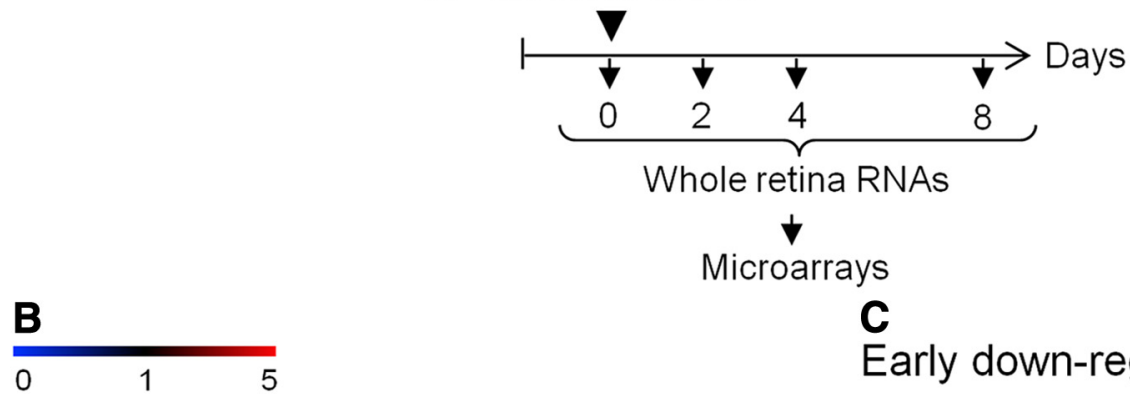

C

Early down-regulated genes
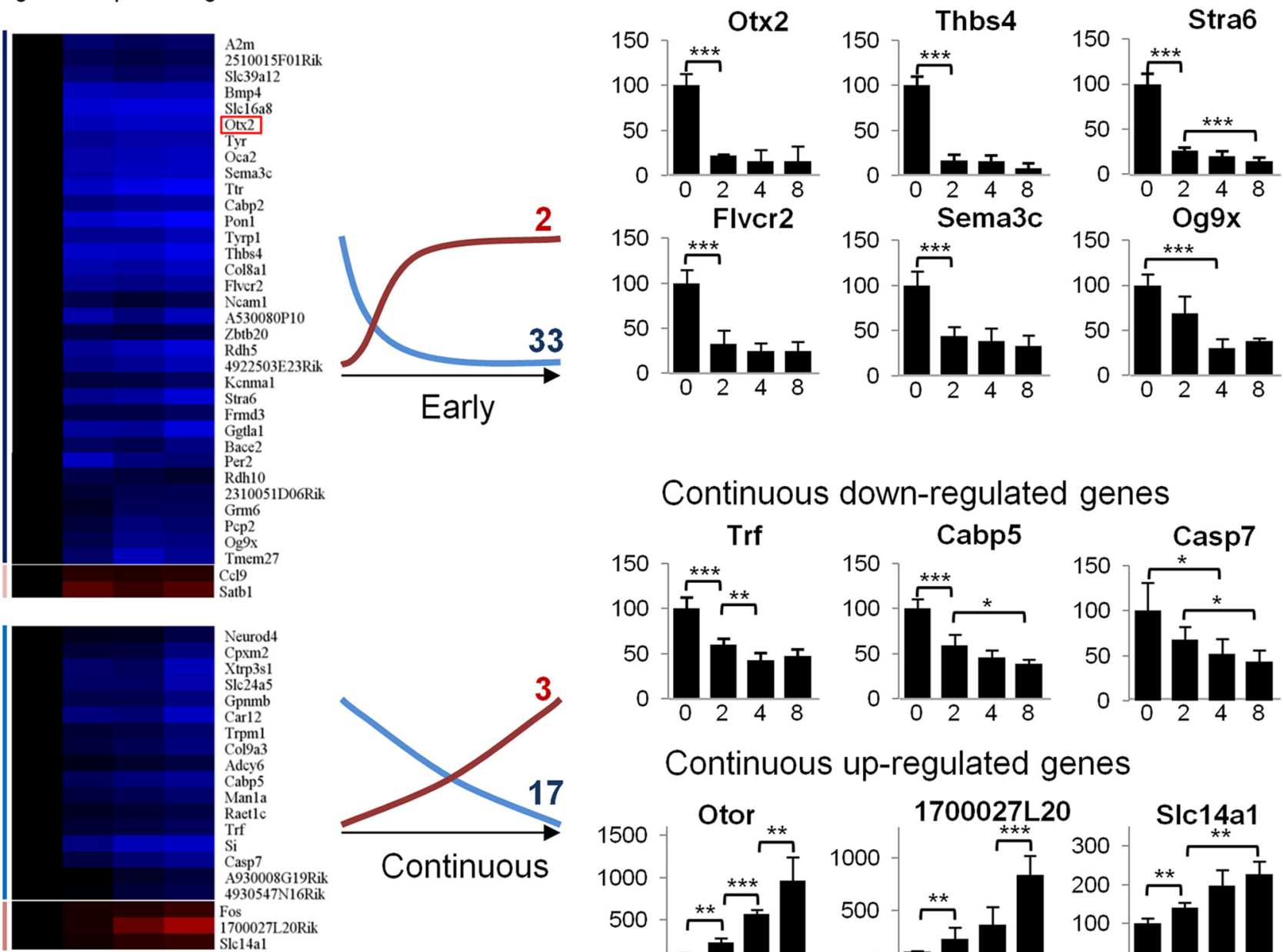

Continuous down-regulated genes

Trf
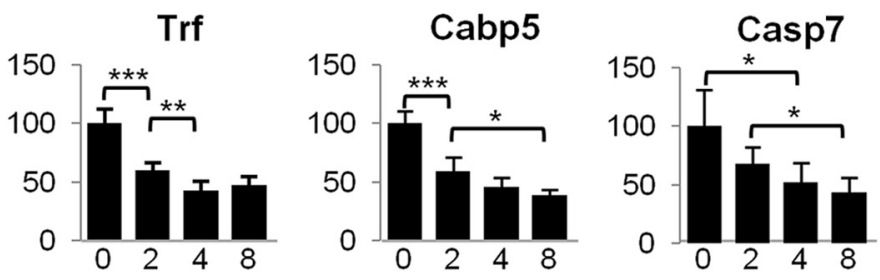

\section{Continuous up-regulated genes}
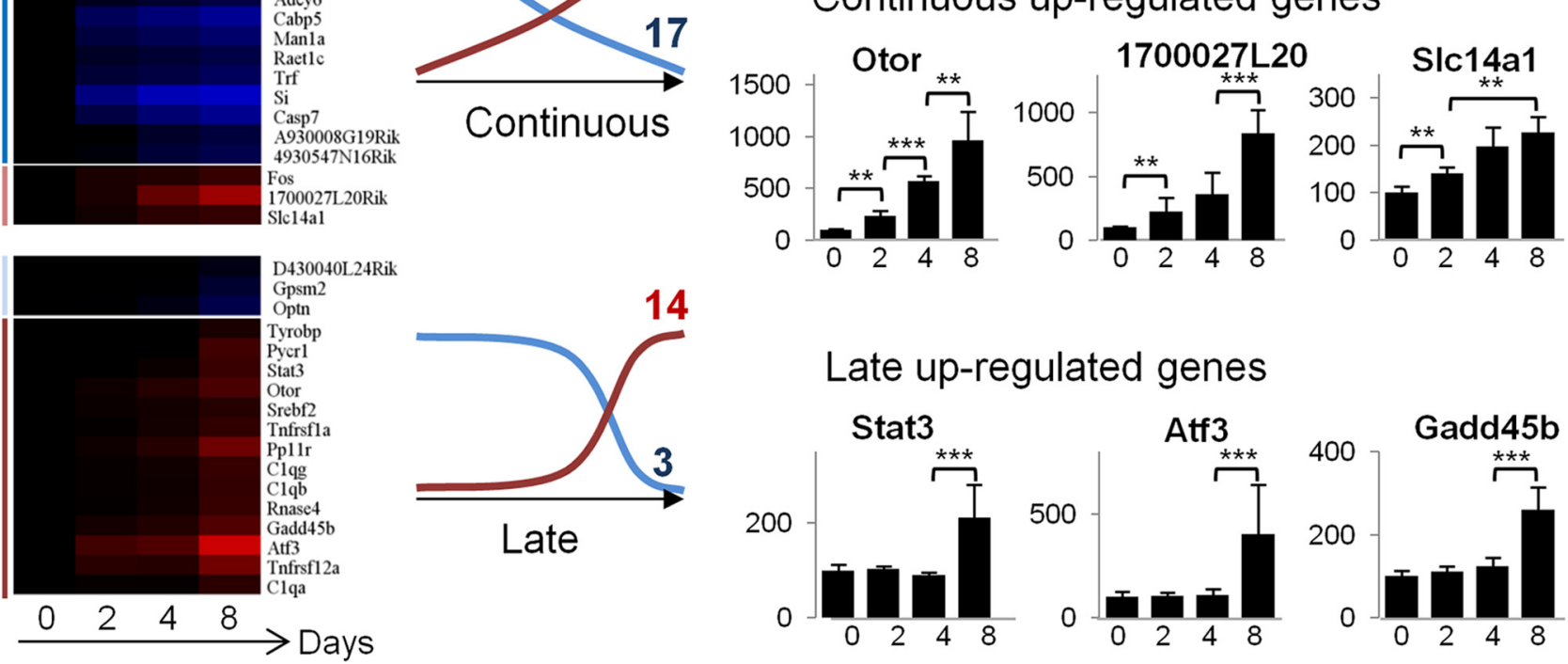

Figure 2. Two waves of gene deregulation are induced after $0 t x 2$ sKO in the mature retina. $\boldsymbol{A}$, Schematic of the sampling for time-series transcriptome analysis. $\boldsymbol{B}$, Clustering of differentially expressed genes after Otx2 sK0. Left, Downregulated and upregulated genes were grouped into three gene sets according to their kinetics of variation: early, continuous, and late. Heat map shows the averaged expression relative to day 0 for each time point. Right, Schematics of kinetic profile for each gene set with the number of downregulated (blue line) and upregulated (red line) genes. C, Representative examples of qRT-PCR validation of all classes of deregulated genes after Otx2 sKO in the adult retina. Histograms represent percentage of mRNA level at each time relative to level on day 0 . Genes are categorized according to their profile in the time-series gene expression analysis. All experiments were done in triplicate. Error bars indicate SD. Significant changes between relevant consecutive time points: ${ }^{*} p \leq 0.05$ (Student's $t$ test); ${ }^{* *} p \leq 0.01$ (Student's $t$ test); ${ }^{* * *} p \leq 0.001$ (Student's $t$ test). 
Table 1. Properties of genes deregulated in 0tx2 sK0 retinas

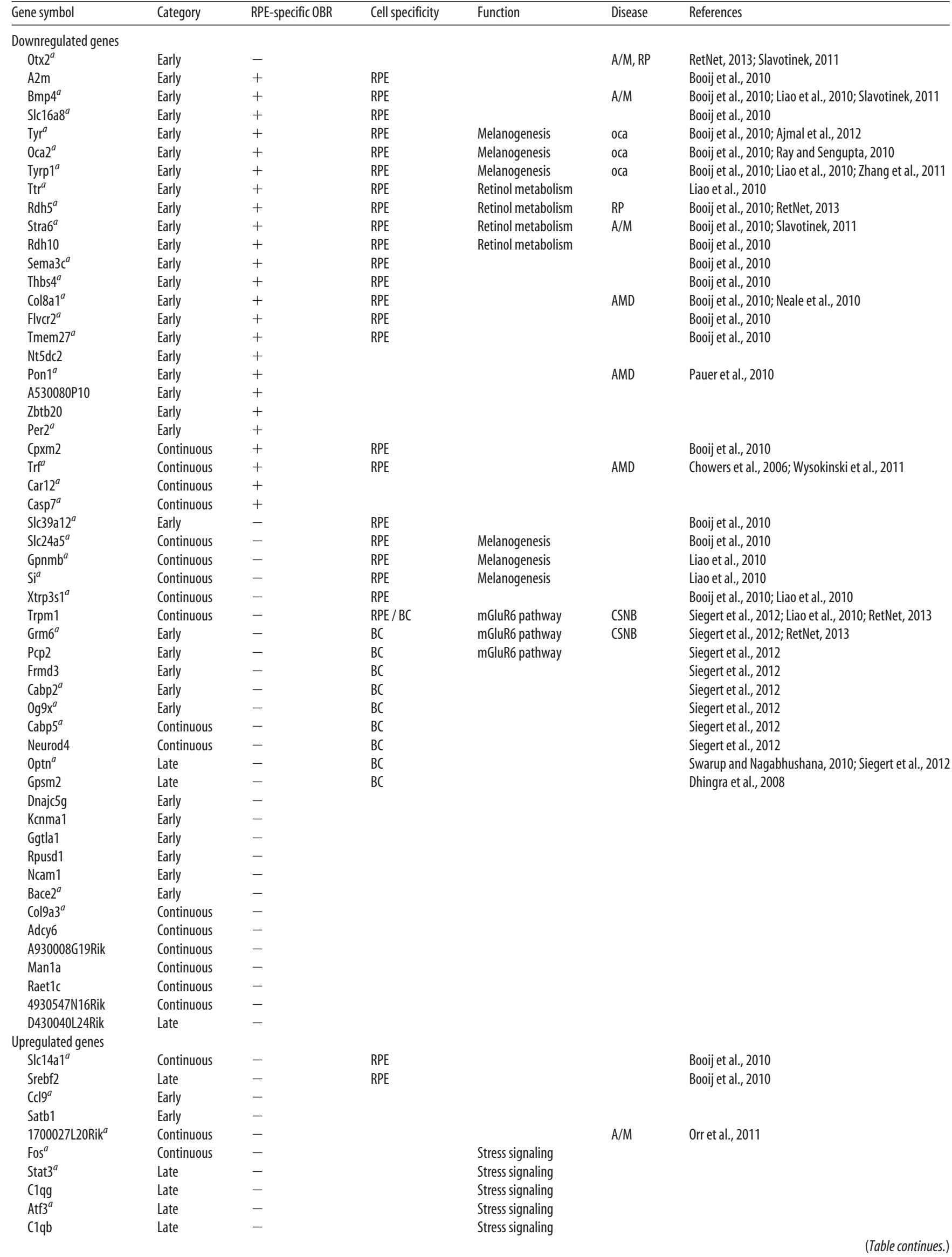


Table 1. Continued

\begin{tabular}{|c|c|c|c|c|c|c|}
\hline Gene symbol & Category & RPE-specific OBR & Cell specificity & Function & Disease & References \\
\hline C1qa & Late & - & & Stress signaling & & \\
\hline Tnfrsf1a & Late & - & & Stress signaling & & \\
\hline Gadd $45 b^{a}$ & Late & - & & Stress signaling & & \\
\hline Tnfrsf12a & Late & - & & Stress signaling & & \\
\hline Tyrobp & Late & - & & & & \\
\hline Pycr1 & Late & - & & & & \\
\hline Otor ${ }^{a}$ & Late & - & & & & \\
\hline Pp11r & Late & - & & & & \\
\hline Rnase4 & Late & - & & & & \\
\hline
\end{tabular}

${ }^{a}$ Gene tested for qRT-PCR validation. All variations were validated, except for 0 ptn and C(19.

OBR, presence of an 0tx2 bound region in RPE nuclei. Associated disease abbreviations: A/M, Anophthalmia/microphthalmia; RP, retinitis pigmentosa; 0ca, oculocutaneous albinism; CSNB, congenital stationary night blindness.

A

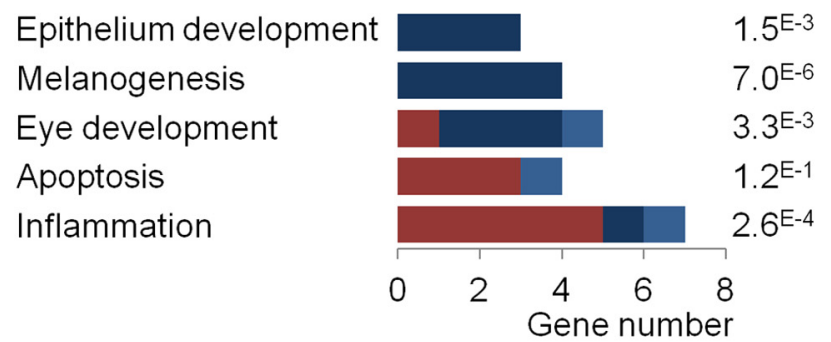

Early down $\square$ Continuous down $\square$ Late up

C

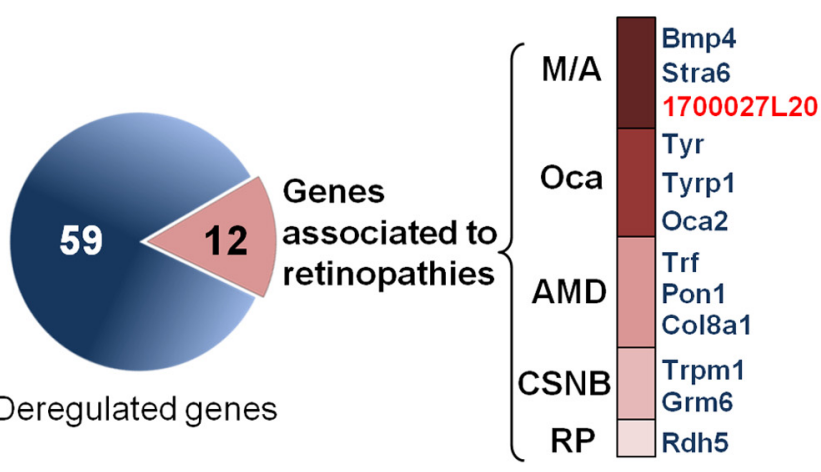

B

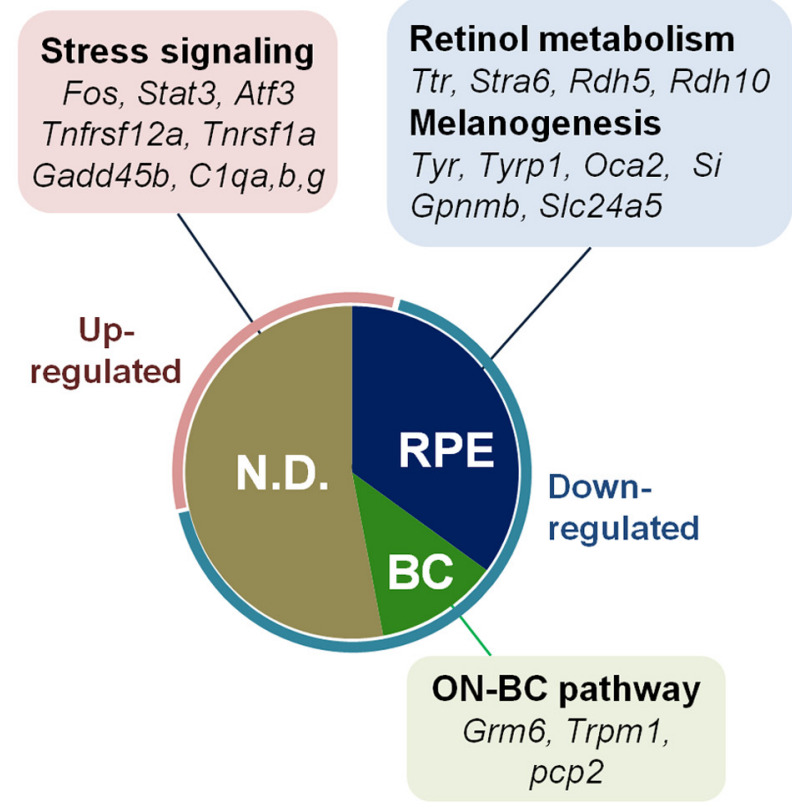

Figure 3. Functional categorization of genes deregulated after Otx2 ablation. $\boldsymbol{A}$, Gene Ontology analysis of deregulated genes. Histograms represent the number of color-coded genes of each category, with statistical significance shown by $p$ value. $\boldsymbol{B}$, Distribution of deregulated genes according to retinal cell-type specificity and functional clusters: genes exclusively expressed in RPE cells (blue, 34\%), in bipolar cells (green, 14\%), or not determined or not specific of a cell-type (N.D., brown, 52\%). Distribution of downregulated (light blue) and upregulated (light red) genes is shown in the surrounding ring. Functional clusters identified within each group are shown with gene symbols. BC, Bipolar cell. $\boldsymbol{C}$, Relevance to human retinopathies. Red portion of chart represents deregulated genes related to five types of retinopathies. Gene symbols of downregulated (blue) and upregulated (red) genes are indicated in front of corresponding retinopathies. M/A, Microphthalmia/anophthalmia; Oca, oculocutaneous albinism; CSNB, congenital stationary night blindness; RP, retinitis pigmentosa.

gene expression profiling, immediately after $O t x 2$ gene ablation, and before degeneration onset, to focus on initial genetic events.

Otx2 deletion was induced at P30, and whole retina RNA was extracted on days $0,2,4$, and 8 after induction (Fig. 2A). For each time point, three mice were used. Each sample was independently processed and applied to a Codelink mouse whole genome microarray, yielding 12 datasets. Differential expression was analyzed for all combinations of different time points using moderated $t$ tests from Bioconductor (Gentleman et al., 2004). We found 71 significantly genes deregulated at at least one of the time points, of which 52 (74\%) showed downregulation (Fig. 2B; Table 1). To confirm microarray results, 39 of the 71 deregulated genes were randomly selected to quantify their mRNA expression levels using qRT-PCR at days $0,2,4$, and 8. Thirty-seven of 39 tested genes (96\%) exhibited the same profile, thus validating our microarray results (Fig. 2C; Table 1).

Next, we analyzed the kinetics of expression variation of all deregulated genes. Using K-mean clustering with Mev software (Saeed et al., 2006), we found three different kinetic profiles (Fig. 2B): (1) Early genes (33 downregulated; 2 upregulated) showed strongest changes of expression between days 0 and 2 and moderate or no further variation. As expected, the full-length $O t \times 2$ transcript fell into this category. (2) Continuous genes (17 downregulated and 3 upregulated) showed steady variation all along the time course. (3) Late genes (3 downregulated and 14 upregulated genes) changed their level of expression only between days 4 and 8 . Interestingly, $>94 \%$ of downregulated genes belong to early and continuous profiles, whereas $73 \%$ of upregulated genes 
A

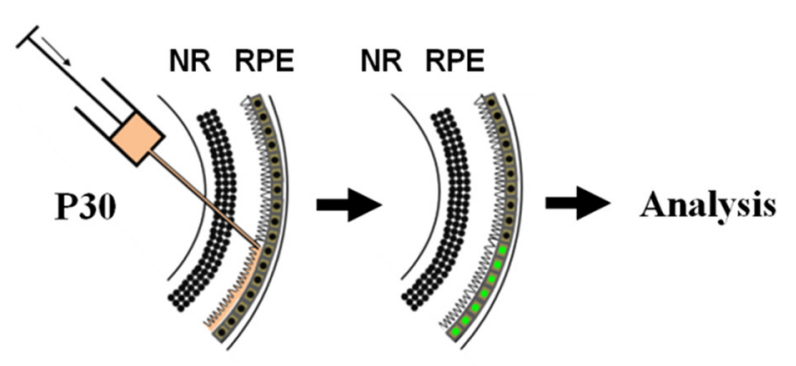

\section{RPE-specific \\ Otx2 KO}

C

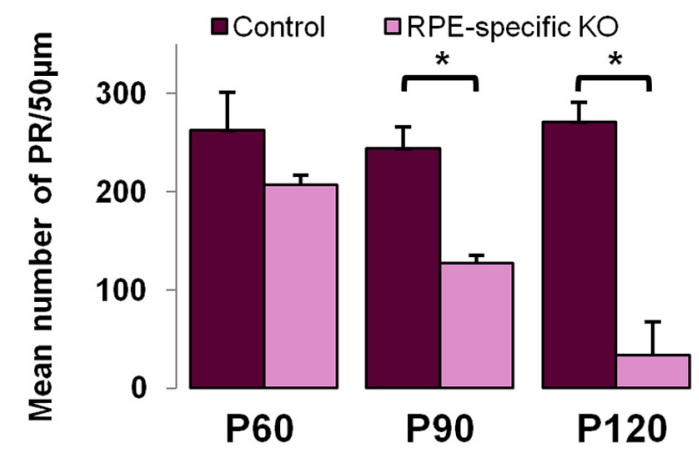

\section{B}

Control

P120
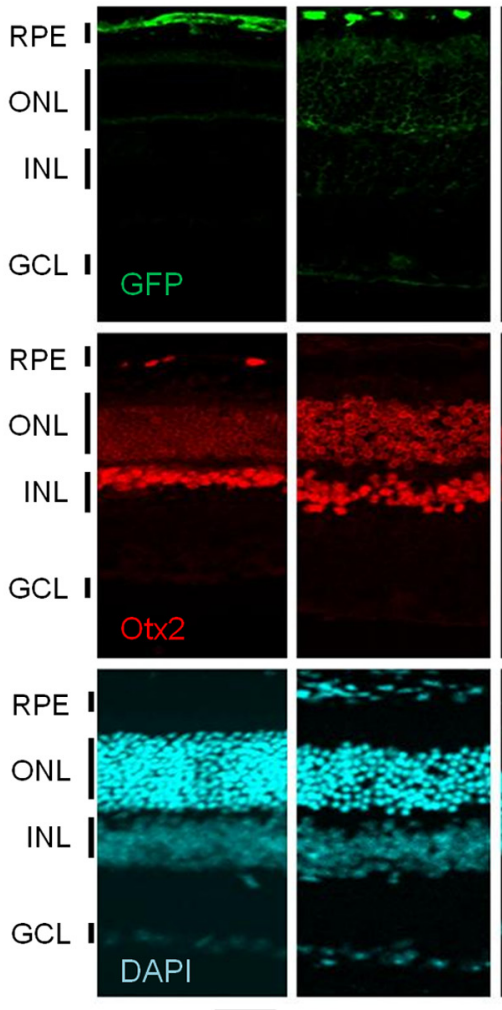
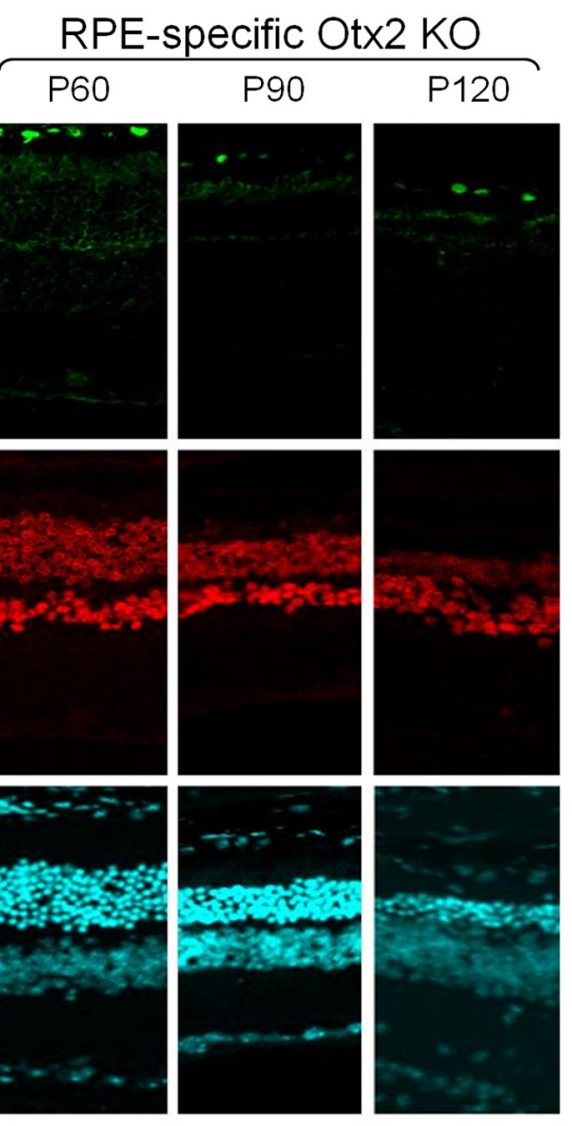

D

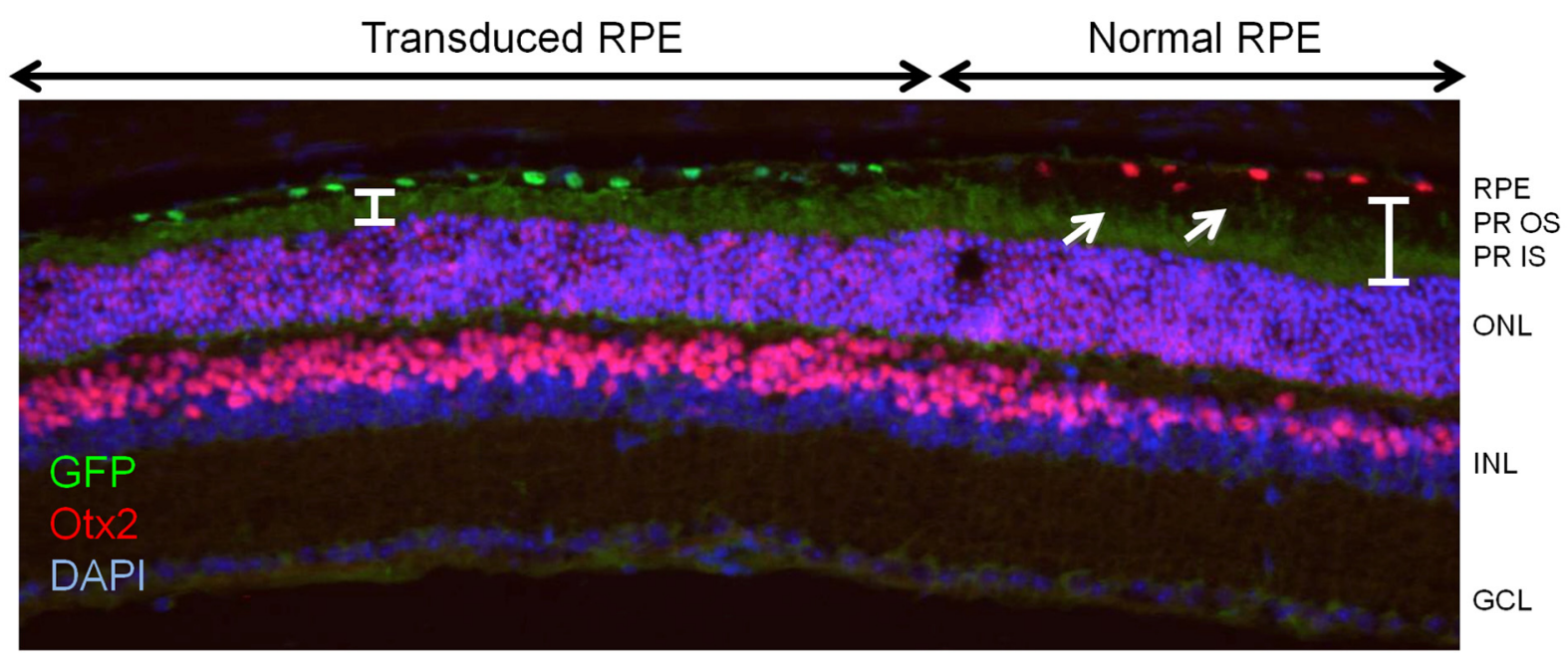

Figure 4. $0 \mathrm{tx} 2 \mathrm{RPE}$-specific functions are necessary for photoreceptor maintenance. $A$, Schematic of RPE-specific Otx2 conditional knock-out by subretinal injection of Cre-expressing lentivirus in P30 Otx $2^{\text {flox/flox }}$ mice. B, Immunostaining of GFP (green), Otx2 (red), and DAPI staining on vertical sections of control and RPE-specific Otx2 K0 retinas at the indicated age, showing sustained Cre expression, RPE-specific Otx2 ablation, and progressive loss of photoreceptors in RPE-K0 mice. C, Cell counts in the photoreceptor layer of retinal sections of control or RPE-specific Otx2 conditional knock-out mice at indicated ages. Normalized fields of the same eye area were used. Cell numbers were determined by counting the nuclei in a $50-\mu \mathrm{m}$-wide region of retinal section located at equal distance from the ora serrata and the optic disk. For each point, three eyes were dissected. For each, three different regions were counted. Mean cell numbers are indicated for each condition. Error bars indicate SD. ${ }^{*} p \leq 0.001$. D, Coimmunostaining of GFP, 0tx2, and DAPI staining on a vertical section of a P60 0tx2 ${ }^{f l o x}{ }^{\prime f l o x}$ retina showing adjacent (re-expressing (transduced RPE) and nonexpressing areas. Tick bars indicate the thickness of photoreceptor segment in the corresponding areas; arrows indicate the preserved outer segments in noninfected area. Scale bar, $50 \mu \mathrm{m}$.

belong to the late profile. These results highlight two sequential waves of gene deregulation: in the first wave, loss of Otx2 is rapidly followed by downregulation of 50 genes. In the second wave, 17 genes are upregulated.
To gain insights into the biological response triggered by Otx2 ablation, we first searched each cluster of deregulated genes for enriched functions using Gene Ontology (Fig. 3A). We found that early and continuous downregulated genes were associated 
A

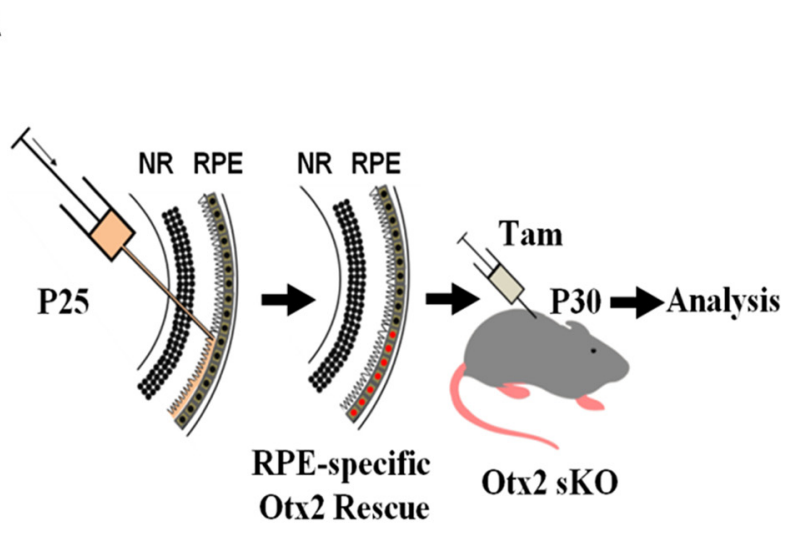

C

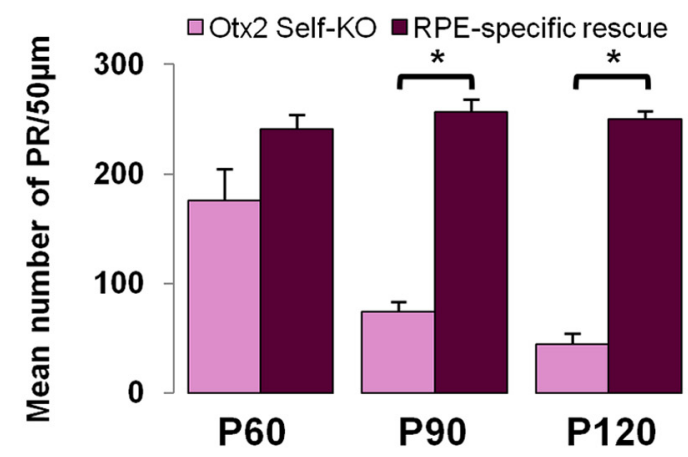

B

\section{sKO} P120
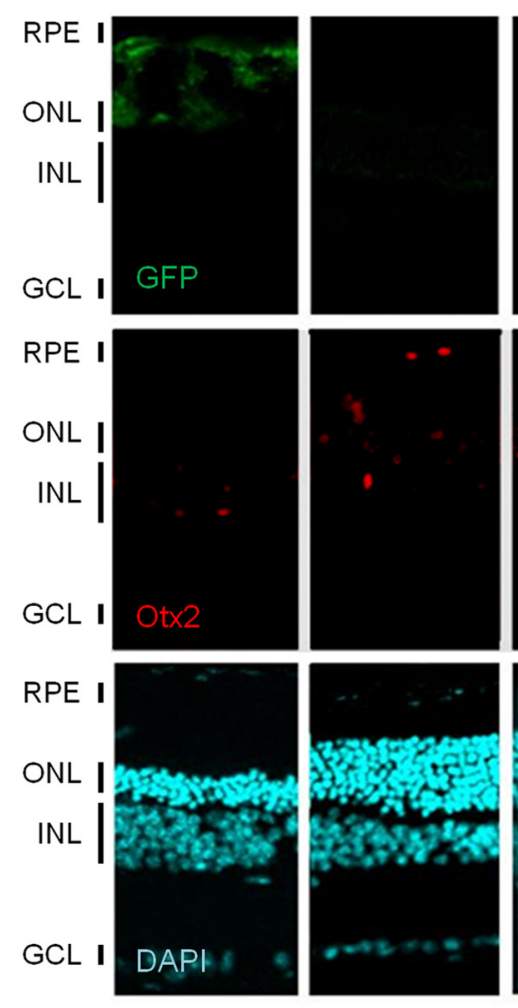

RPE-specific Otx2 rescue
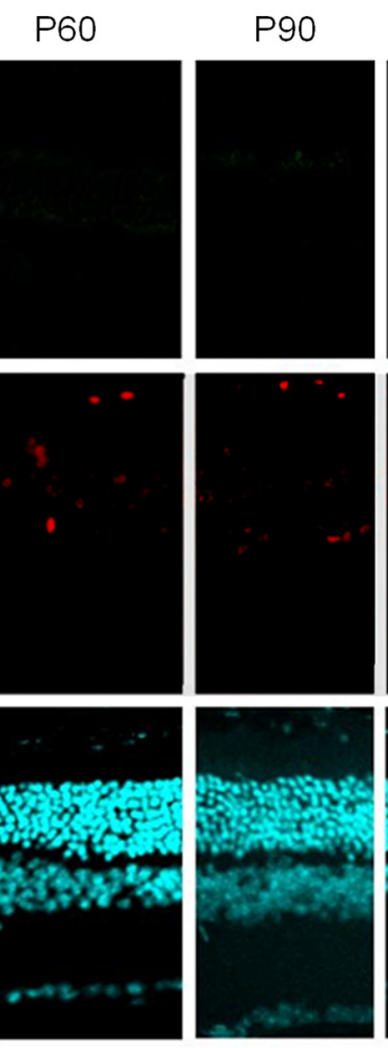

P120
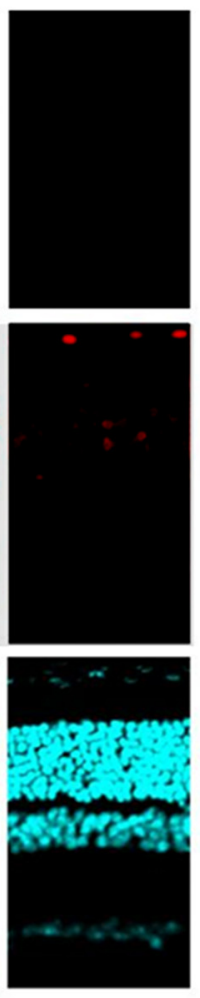

Figure 5. Otx2 RPE-specific functions are sufficient for photoreceptor maintenance. $A$, Schematic of the RPE-specific rescue protocol. Lentivirus-expressing GFP (sK0) or Otx2-HA (RPE-specific rescue) were injected at P25 in the subretinal space of $0 t \times 2$ flox/(reERT2 mice, and sKO was triggered by tamoxifen (Tam) administration at P30. $\boldsymbol{B}$, Immunostaining of GFP (green), 0 tx2 (red), rhodopsin (orange), and DAPI staining on vertical section of $s K 0$ and RPE-specific Otx2 rescue retinas at the indicated age, showing sustained RPE-specific 0 tx 2 expression and maintenance of photoreceptors in RPE-KO mice. C, Cell counts in the photoreceptor layer of retinal sections of control or RPE-specific rescued mice at indicated ages. Cell numbers were determined as in Figure 4. For each, three different regions were counted. Mean cell numbers are indicated for each condition. Error bars indicate SD. ${ }^{*} p \leq 0.001$. Scale bar, $50 \mu \mathrm{m}$.

with RPE-specific functions, such as melanogenesis $(p \leq$ 0.00001 ), epithelial development ( $p \leq 0.001$ ), and eye development $(p \leq 0.01)$, whereas upregulated genes of the late category related to inflammatory response ( $p \leq 0.00001)$ and apoptosis $(p \leq 0.2)$. We next used molecular signatures of mouse neural retina cell types (Siegert et al., 2012) and human RPE (Booij et al., 2010; Liao et al., 2010) to assign cell specificity to all of the 71 deregulated genes (Fig. 3B). Twenty-five genes (35\%, mostly downregulated) were specific to RPE cells, with 10 of them involved in two major RPE pathways: melanogenesis (Tyr, Tyrp1, Oca2, Gpnmb, Si, and Slc24a5) and retinol metabolism (Ttr, Stra6, $R d h 5$, and $R d h 10$ ). In line with Otx2 expression in bipolar cells, nine downregulated genes (12\%) were specific to this cell type, with three of them involved in ON-bipolar mGluR6 pathway (Grm6, Trpm1, and pcp2). Yet, no photoreceptor-specific genes were found among the deregulated genes. Therefore, half of the early downregulated genes were specific to one cell type, mostly RPE cells. By contrast, the majority of late upregulated genes were not specific to any retinal cell type. Together, these observations suggest a two-step scenario where Otx2 loss initially deregulates genes controlling key RPE-specific functions. Then, these RPE alterations elicit subsequent activation of cell stress signaling and inflammation genes, initiating photoreceptor degeneration.

We aimed to examine whether the identified genes had already been known to be involved in retinal diseases, and we there- fore scoured retinal disease databases. Of the 71 genes, $12(17 \%)$ were associated with retinopathies. In humans, mutations of these genes were reported to cause microphthalmia or anophthalmia (Stra6, Bmp4, and 1700027L20Rik), oculocutaneous albinism (Tyr, Tyrp1, and Oca2), susceptibility to age-related macular degeneration (AMD) (Pon1, Colsa1, and Trf), congenital stationary night blindness (Grm6 and Trpm1) and retinitis pigmentosa (Rdh5) (Fig. 3C). These findings emphasize the capacity of our model to identify novel human retinopathiesrelated genes.

\section{RPE-specific ablation of Otx2 recapitulates photoreceptor disease}

Our analyses suggested that $O t \times 2$ ablation primarily affects RPE function, which subsequently initiates photoreceptor degeneration. To confirm this hypothesis, we performed RPE-specific ablation of Otx2 and asked whether it could recapitulate the sKO phenotype. We used subretinal injection of HIV-1-derived lentivirus. In the mature retina, beyond P15, lentivirus vector delivery at this site is known to target exclusively RPE cells because of the outer limiting membrane that functions as a barrier (Calame et al., 2011; Kostic et al., 2011). A suspension of lentivirus expressing a CreN-GFP fusion protein was injected in the subretinal space of one eye of $\mathrm{Otx}^{+/++}$or Otx $2^{\text {flox/flox }}$ mice at P30 (Fig. 4A), and consequences were examined at P60, P90, and P120 (Fig. 4B). At least three mice $(n=3-6)$ were analyzed at each stage. As 
A

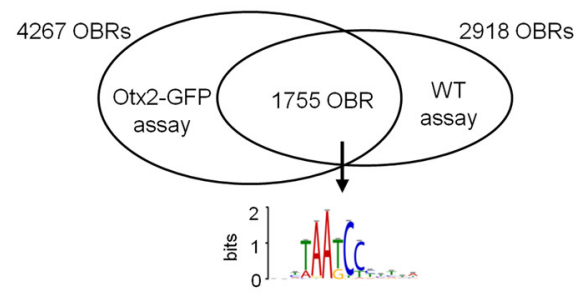

C

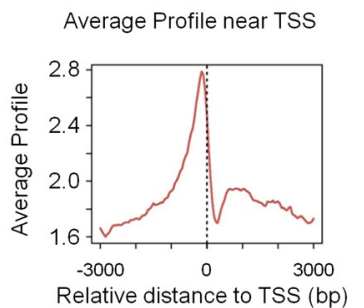

B

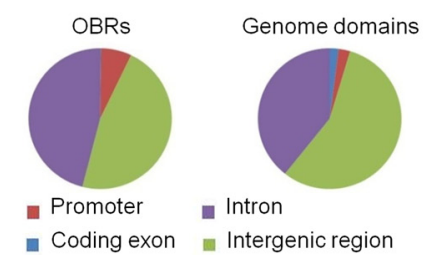

D

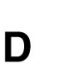

D

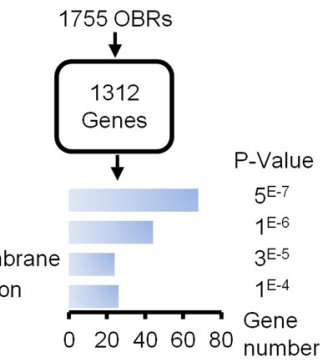

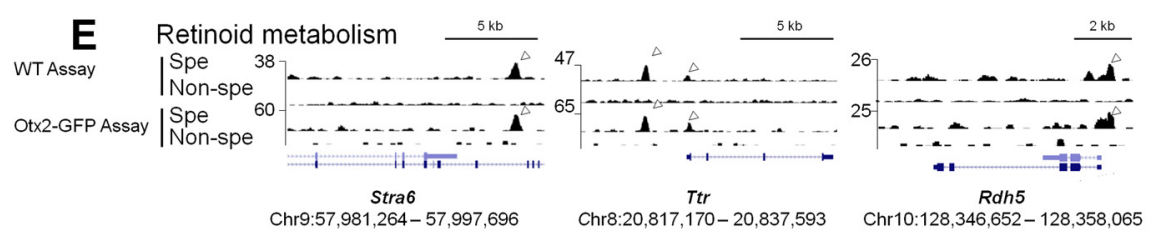
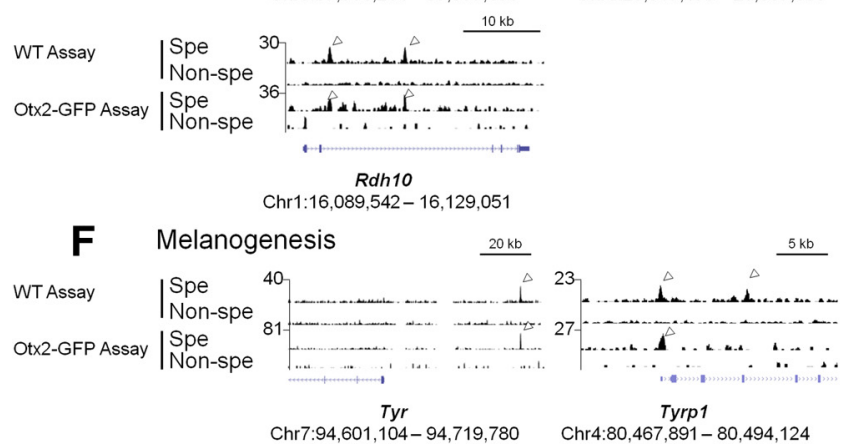

Figure 6. Identification of 0 tx2 targetome in RPE cells by dual ChIP-seq analysis. $\boldsymbol{A}$, Venn diagram comparison of identified OBRs in the RPE genome by Otx2-GFP and WT ChIP-seq assays. Weight matrix of overrepresented positions is shown below (E-value $=1.0 \mathrm{e}-313$ ). $\boldsymbol{B}$, Comparison of the distribution of common OBRs (left) and genome domains (right): promoters (defined as $3 \mathrm{~kb}$ upstream TSSs, red), introns (purple), coding exons (blue), and intergenic regions (green). C, Distribution of common OBRs in a concatenated $6 \mathrm{~kb}$ window centered on TSSS. D, OBR association to closest genes and Gene Ontology analyses. $\boldsymbol{E}, \boldsymbol{F}$, Visualization of 0tx2 ChIP-seq peaks obtained with WT and 0tx2-GFP assays for retinol metabolism $(\boldsymbol{E})$ and melanogenesis $(\boldsymbol{F})$ genes. Distribution of sequence tags (black areas) obtained with specific and nonspecific antibodies is shown on the genome for WT (top rows) and 0tx2-GFP (bottom rows) assays. The numbers are the peak summit counts. Regions significantly enriched for each assay (arrows) were defined as OBRs. For each gene, position of exons (blue box) and introns (blue line) is shown below with gene symbol and genomic coordinates of the visualized genome portion. ECM, Extracellular matrix; BL, basolateral; Chr, chromosome.

a control, a suspension of lentivirus-expressing GFP was injected in the contralateral eye. We used lentivirus amounts previously determined to yield robust expression of exogenous genes (Pang et al., 2006; Kostic et al., 2011). Using such a dose, the retina exhibited two exclusive aspects (Fig. 4D): in the region corresponding to the injection bleb, $100 \%$ of RPE cells expressed nuclear GFP, hence CreN protein. Transition at the edge of the bleb was sharp. Outside the region of injection, neither GFP nor Cre expression was found. We never observed any mosaic pattern in the injected region, suggesting efficient topic infection and expression of HIV-derived lentivirus, which results in an all-ornone situation. In eyes injected with recombinant CreN-GFP lentivirus, nuclear expression of CreN-GFP was consistently restricted to RPE cells facing the site of injection both in WT and Otx $2^{\text {flox/flox }}$ mice. This expression pattern was maintained during the

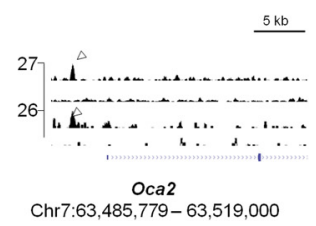

whole period of observation, demonstrating cell-specific integration and expression of the lentiviral vector (Fig. 4B). As expected, Otx2 expression was abolished in the infected RPE area of Otx $2^{\text {flox/flox }}$ mice but was fully maintained in infected RPE cells of $O t \times 2^{+/+}$mice. Degeneration of photoreceptor cells was observed exclusively in retinal areas in contact with the knock-out RPE cells of Otx $2^{\text {flox/flox }}$ mice (Fig. $4 B, D$ ): at P60, we observed shortening of the photoreceptor outer segment. At P90, we found a $48 \%$ decrease of the photoreceptor cell number; and at P120, the decrease exceeded $85 \%$ indicating progressive photoreceptor death (Fig. 4C). The kinetics of the observed photoreceptor loss closely mirrored the one observed in sKO mice. Similarly to the Otx2 sKO model, the other cell layers were not affected. Contralateral retinas infected with a GFP-expressing vector appeared normal. This demonstrates that Otx2 expression is essential in RPE cells to prevent photoreceptor degeneration.

\section{RPE-specific expression of Otx2 prevents photoreceptor degeneration in the sKO retina}

We next examined whether Otx2 expression in RPE is sufficient for photoreceptor maintenance. We constitutively expressed Otx2 in RPE cells in animals with an Otx2 mutant retina to ask whether such expression is sufficient to prevent photoreceptor degeneration. To this end, a suspension of lentivirus driving expression of $\mathrm{HA}$ tagged Otx2 protein was injected in the subretinal space of Otx $2^{\text {CreERT2/flox }}$ mice at $\mathrm{P} 25$, and Otx2 sKO was triggered by intraperitoneal injection of tamoxifen at P30 (Fig. 5A). Lentivirus injection was done $5 \mathrm{~d}$ before induction of sKO to avoid a transient lack of Otx2 in the RPE compartment, as 3-4 d are required for lentivirus integration and expression. This resulted in global Otx2 extinction, except in the infected RPE cells. Retina histology was examined at P60, P90, and P120 and compared with contralateral eyes infected with the GFP expressing vector, at P120 (Fig. $5 B)$. At least three mice $(n=3-6)$ were examined at each stage. Despite the loss of Otx 2 in photoreceptor and bipolar cells, photoreceptor outer segments as well as outer nuclear layer thickness remained unaltered in areas contacting RPE cells that constitutively expressed Otx2, even 3 months after Ot $x 2$ sKO (Fig. $5 C$ ). In contrast, photoreceptor degeneration was found outside these areas. This experiment demonstrates that Otx2 expression is dispensable in both photoreceptor and bipolar cells and that RPE-specific expression of Otx2 is sufficient for photoreceptor maintenance in the mature retina.

The present phenotypic analysis shows that RPE-specific Otx2 ablation fully recapitulates the degeneration of photoreceptor cells observed in Otx2 sKO mice and that RPE-specific Otx2 expression protects Otx2-ablated photoreceptors from degen- 
eration. Therefore, in our Otx2 sKO model, photoreceptor degeneration occurs as a secondary consequence of RPE dysfunction.

\section{Identification of Otx 2 targetome in adult RPE cells}

Otx2 appears both necessary and sufficient in RPE cells to prevent photoreceptor degeneration in our model. This prompted us to focus on genes regulated by Otx2 in the RPE layer. To obtain a global view of the repertoire of Otx2 target genes in these cells, we isolated adult RPE nuclei and analyzed the genome occupancy of Otx2 by ChIP followed by massive sequencing (ChIP-seq). To enhance the reliability of identified OBRs, we performed two parallel experiments using either Otx $2^{\text {Otx2-GFP/+ }}$ knock-in mice expressing an Otx2-GFP fusion protein (Fossat et al., 2007) together with an anti-GFP antibody, or WT mice together with an anti-Otx2 antibody. This generated two independent sets of data, thereafter referred to as the WT and the Otx2-GFP assays. After sequencing, peak calling was performed using MACS algorithm (Feng et al., 2012). WT and Otx2-GFP assays yielded 2918 and 4267 OBRs, respectively, among which 1755 overlapped, showing strikingly similar distribution patterns with the exact same position on the genome, and similar relative enrichment (Fig. 6A,E,F). ChIP-seq analysis was further performed using this restrained set of 1755 high-confidence OBRs. Importantly, de novo motif discovery run on the 500 highest peaks identified strong enrichment for TAATCC motif (MEME E-value $\left.=1.0 \times 10^{-313}\right)$, previously known as Otx2 high-affinity binding site (Chatelain et al., 2006) (Fig. 6A). This supported specificity of identified OBRs. Together, these results confirm a high-quality dataset of 1755 OBRs.

The 1755 OBRs had a median width of $617 \mathrm{bp}$ and an average height of 36 tags. To further characterize their location, we compared them with the UCSC RefSeq gene database using CEAS (Shin et al., 2009). OBRs did not follow a random distribution across the genome but appeared overrepresented in the vicinity of genes: $49.5 \%$ of them located within a gene region extending from $3 \mathrm{~kb}$ upstream transcription start sites (TSS) to $3 \mathrm{~kb}$ downstream the $3^{\prime}$ UTR (Fig. $6 B$ ). In total, $47.2 \%$ of all OBRs located within introns, $0.2 \%$ within exons, $0.7 \%$ within the $5^{\prime}$ UTR, and $1.4 \%$ within the $3^{\prime}$ UTR. The remaining OBRs, located farther than $3 \mathrm{~kb}$ upstream or downstream of the annotated genes, were scored as intergenic. Otx2 binding was enriched in promoter regions, with $7 \%$ of peaks located $<1 \mathrm{~kb}$ upstream TSS, fitting with transcriptional regulation activity (Fig. 6C). Based on closest relative distance to TSS, the 1755 OBRs could be assigned to 1312 genes, whose biological functions were examined using Gene Ontology (Fig. 6D). We found that Otx2 binds to chromatin regions close to genes involved in cell adhesion $\left(p=8 \times 10^{-7}\right)$, extracellular matrix constituent $\left(p=1 \times 10^{-6}\right)$, and basolateral plasma membrane $\left(p=3 \times 10^{-5}\right)$, which are major features of epithelial cells. As RPE cells are the only epithelial cells in the retina, this confirms cell-type specificity of identified OBRs. Genes involved in regulation of cell differentiation were also enriched $\left(p=1 \times 10^{-4}\right)$, in accordance with Otx2 embryonic functions in RPE (Martinez-Morales et al., 2001). These findings suggest that $\mathrm{Otx} 2$ is involved in the regulation of genes of structural and functional importance for adult RPE cells.

To characterize the core set of Otx2 direct target genes in the $\mathrm{RPE}$, we searched all deregulated genes following Otx2 sKO (Fig. 2) for the presence of OBR (Table 1). Twenty-four downregulated genes possessed an associated OBR, with seven of them not previously recognized as RPE-specific: Pon1, Nt5dc2, Zbtb20, Per2, Car12, Casp7, and A530080P10. In RPE chromatin, Otx2 was found to bind sites proximal to all four genes involved in retinoid metabolism (Fig. $6 E$ ). The same situation was observed for three genes controlling melanogenesis (Fig. $6 F$ ).

We tested the direct binding of Otx2 on a subset of selected OBRs by assessing their specific DNA enrichment by PCR in independent ChIP experiments (Fig. 7). Five DNA regions corresponding to ChIP-seq peaks of four representative genes expressed in the RPE (Tyrp1, Slc16a8, Rdh5, and Ttr) were tested. All of them showed specific enrichment when using anti-Otx2 or anti-GFP antibodies and WT or Otx $2^{\text {Otx2-GFP/+ }}$ RPE chromatin, respectively, indicating true Otx2 binding. On the contrary, a DNA region of the Ttr locus outside a peak did not show any enrichment, confirming the specificity of OBRs (Fig. 7, PCR3). We thus concluded that Otx 2 binds to and coordinately regulates the expression of several sets of genes, each devoted to important RPE functions. The synchronized perturbation of these functions by simultaneous loss of Otx 2 function in all RPE cells, rather than other Otx2 functions in the neural retina, induces subsequent stress and inflammation responses that stand at the origin of the cognate photoreceptor apoptosis (Fig. 8). Noteworthy, none of the nine bipolar-specific genes displayed any OBR, confirming the cell specificity of ChIP experiments. Moreover, none of the 19 upregulated genes exhibited any associated OBR, indicating that their induction was an indirect event. Together, this analysis confirmed that the genes downregulated in the first wave after Otx2 sKO were direct Otx2 targets in RPE, whereas genes of the second wave were induced as a secondary consequence of these initial downregulations.

\section{Discussion}

Our study demonstrates that Otx2 plays a critical role in the maintenance of photoreceptors and the prevention of late-onset neuronal degeneration in the adult retina, through its activity in RPE cells. First, soon after Otx 2 ablation, ERG reveals a dramatic 

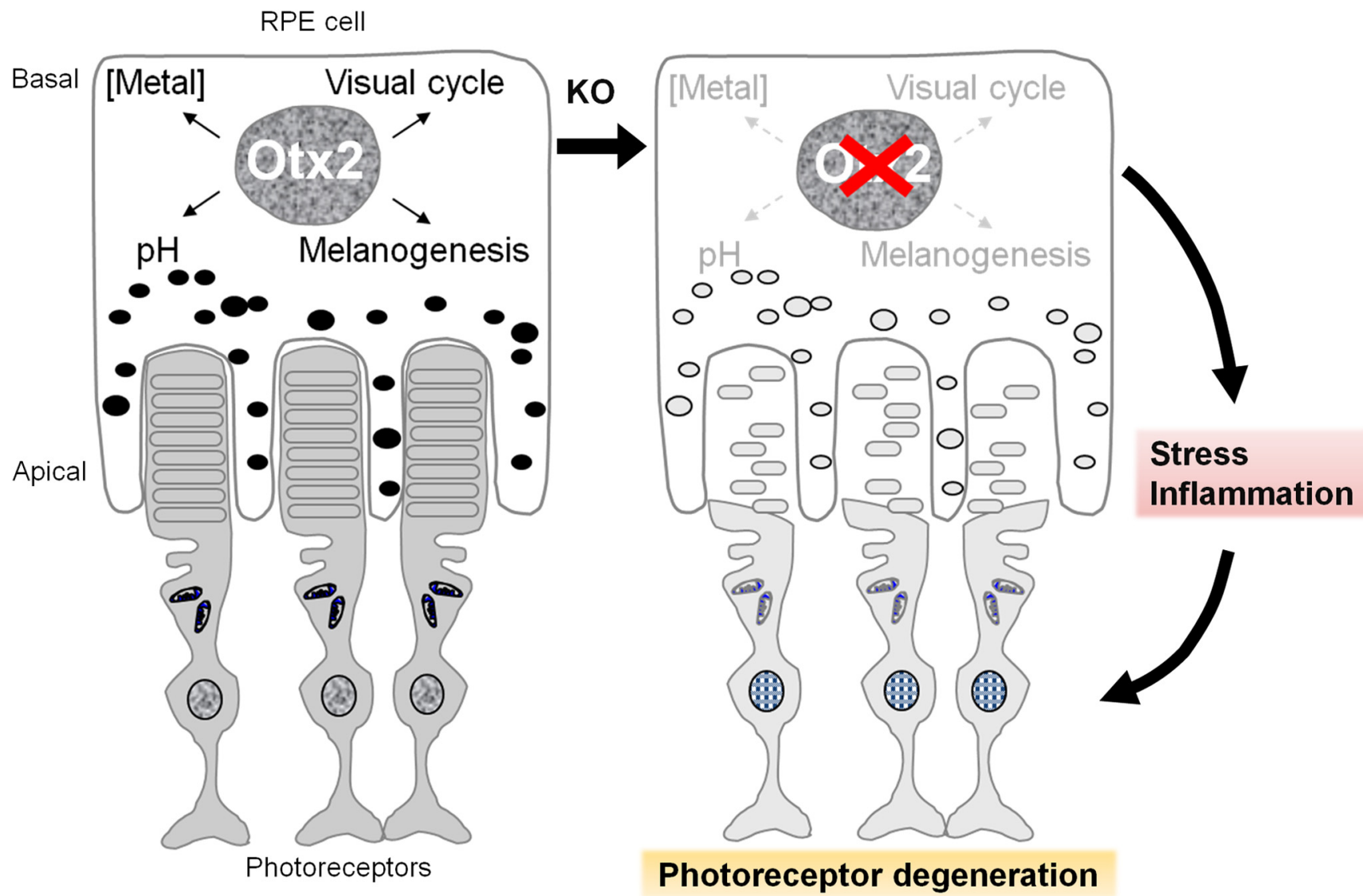

Photoreceptor degeneration

\section{New candidates and markers for retinal diseases of RPE origin (AMD, RP)}

Figure 8. Model for photoreceptor degeneration in adult Otx2 sKO mice. In the adult retina, 0tx2 coordinates the expression of homeostatic and metabolic functions in RPE cells. Loss of Otx2 primarily induces synchronous deregulation of these RPE functions, which secondarily provoke cell stress gene activation that leads to photoreceptor degeneration. The deregulated genes provide both new candidates for photoreceptor homeostasis and new makers for clinical diagnosis of retinal diseases of RPE origin.

alteration of the c-wave pattern, which reflects altered RPE and/or Müller cell response to light (Hanitzsch and Lichtenberger, 1997). Second, gene expression analysis shows that half of the genes downregulated upon Otx2 ablation are specifically expressed in RPE cells, with 24 of them demonstrated to be direct Otx2 target genes by cell-specific ChIP-seq analysis. Third, using a lentivirus-mediated functional approach to drive Otx2 knockout or ectopic expression specifically in RPE cells, we demonstrate that RPE-specific ablation of Otx2 fully recapitulates the photoreceptor syndrome induced in full retina knock-out and that constitutive Otx2 expression in RPE cells is sufficient to prevent neuronal degeneration in knock-out retina. It therefore appears that Otx2 functions in the mature RPE are both necessary and sufficient to prevent late-onset photoreceptor degeneration.

Critical RPE-specific function for Otx 2 in the adult retina

Otx2 was previously shown to play a role in retina development both in mice and humans, notably by controlling several aspects of RPE, photoreceptor, and bipolar cell determination and differentiation (Martinez-Morales et al., 2003; Nishida et al., 2003; Ragge et al., 2005; Koike et al., 2007; Sato et al., 2007). Here, we identify Otx2 functions in the mature retina by carrying out genome-wide analyses of the molecular events that immediately follow Otx2 gene ablation and subsequently lead to photorecep- tor degeneration in adult mice. We also present the first in vivo ChIP-seq performed on RPE cells.

The time-series transcriptomic analysis of sKO retina captures the dynamics of the genetic response to Otx2 ablation, without the interference of any other processes. As a result, we found a surprisingly small set of 71 deregulated genes. Among these, 49 correspond to early or continuously downregulated genes, whereas 17 upregulated genes appear only in late stages. Although Otx2 has been reported to act as a repressor in the nervous system (Gherzi et al., 1997; Puelles et al., 2003; Steventon et al., 2012), our results strongly support the notion that Otx2 acts as a transcriptional activator in the adult retina. Interestingly, none of the genes regulated by Otx2 during retina development, such as Crx (Nishida et al., 2003), Dct (Takeda et al., 2003), IRBP (Fong and Fong, 1999), Best1 (Masuda and Esumi, 2010), or PKC- $\alpha$ (Koike et al., 2007), was found to be differentially expressed. This suggests that Otx2 function in the adult retina could profoundly differ from its functions during known developmental processes.

We show that Otx2 exerts pleiotropic regulation of metabolic and homeostatic functions in RPE cells: Otx2 controls the expression of several groups of genes involved in RPE-specific functions, especially melanogenesis (Tyrosinase, Tyrp1, Oca2, Scl24a5, Gpnmb, and Si), retinol metabolism (Ttr, Stra6, Rdh5, and Rdh10), pH regulation (Slc16a8 and Car12), and metal concen- 
tration (Slc39a12 and Trf). The simultaneous downregulation of these genes, after Otx2 ablation, induces synchronous impairment of multiple RPE functions. Given the close dependence of photoreceptor cells on RPE protective, nurturing, and maintenance activities (Bramall et al., 2010), it is expected that these cells experience a major stress upon RPE dysfunction, which ultimately may induce their progressive death, thereby accounting for the neuronal degeneration observed in our model.

We found no targets in adult photoreceptors that require Otx2 for their maintenance. This observation is intriguing, given that Otx2 is essential for photoreceptor development (Nishida et al., 2003; Sato et al., 2007). In the mouse embryo, Otx2 is expressed in retinal progenitors at E12.5, where it controls the activation of the Crx gene (Nishida et al., 2003). Otx2 expression in then stably maintained in differentiated photoreceptors (Fossat et al., 2007). One possible explanation of our results is that loss of Otx2 expression in adult photoreceptor cells is masked by the strong and unaffected level of expression of the Otx-related Crx protein in these cells. Crx and Otx 2 share preferential DNA binding to the TAATCC sequence (Chau et al., 2000; Chatelain et al., 2006). Contrary to RPE cells, where only Otx2 is present, Crx and Otx2 could act redundantly in adult photoreceptor cells. Photoreceptor-specific ablation of $\mathrm{Otx} 2$ or Crx or both in the adult retina should help address this issue.

\section{A new model for late-onset neuronal degeneration}

Inherited and complex forms of neuronal degeneration share a common feature: the loss of neurons as a primary or secondary event. In the retina, nonautonomous, RPE-dependent origin for photoreceptor degeneration is found in a significant proportion of both inherited and sporadic diseases, such as mutations in the human MERTK or RPE65 genes, as well as in AMD (Pacione et al., 2003). Although clinical diagnosis and genetic analysis have uncovered a large number of implicated genes (RetNet, 2012), mechanistic understanding of these diseases lags behind. In AMD, which may affect $30 \%$ of individuals $>75$ years old (Ting et al., 2009), slowly accumulated deposits called drusens isolate RPE from the neural retina. As a consequence, RPE cells can no longer take care of cognate photoreceptor cells, which subsequently degenerate (Wright et al., 2010). Because of the heterogeneity of the process, photoreceptor death occurs asynchronously in scattered areas of the retina, which renders the identification of the mechanism involved difficult. In the Otx2 sKO model, all RPE cells undergo a synchronous block of several homeostatic functions, which is much more abrupt than in AMD. Nevertheless, this model is of great value for addressing the mechanisms of photoreceptor death secondary to RPE dysfunction. Indeed, synchronous Otx2 ablation makes it possible to distinguish two consecutive waves of gene deregulation: an early wave of downregulated genes starting $2 \mathrm{~d}$ after Otx2 sKO and a late wave of upregulated genes raising 4-8 d after Otx2 sKO.

The early wave of deregulated-genes, recorded $2 \mathrm{~d}$ after knock-out induction, mostly comprises downregulated genes, half of them being specifically expressed in RPE cells. Their kinetics and the presence of OBR in most of them indicate they represent Otx2 direct target genes. Among them, 12 have been implicated in retinal diseases. For instance, germline mutations disrupting the genes encoding the secreted molecule BMP4 and the Retinol Binding Protein receptor/channel STRA6 have been reported to cause severe developmental eye defects leading to microphthalmia or anophthalmia (Bakrania et al., 2008; Casey et al., 2011). Mutations of the 11-cis-retinol dehydrogenase RDH5 gene, a component of the visual cycle, which allows the regeneration of the 11-cis-retinal chromophore, cause retinitis pigmen- tosa and Fundus albipunctatus diseases in humans (Sato et al., 2004; Sergouniotis et al., 2011; Ajmal et al., 2012). Interestingly, Otx2 also regulates genes involved in late-onset retinal diseases: PON1 and TRANSFERRIN have been linked to high risks for AMD (Chowers et al., 2006; Pauer et al., 2010), whereas COL8A1 is associated with advanced forms of this disease (Neale et al., 2010; Yu et al., 2011). Identification of these disease-related genes supports the idea that the remaining RPE-specific deregulated genes may be highly relevant for human retinal diseases. They provide new candidates to be evaluated in both inherited and sporadic forms of photoreceptor degenerative syndromes, as half of these diseases still lack molecular explanation (Wright et al., 2010).

The model presented here may help uncover mechanisms underlying neuronal degeneration because of our identification of a second wave of gene deregulation. This second wave, starting $4 \mathrm{~d}$ after sKO, could only be revealed by the sharpness and synchrony of Otx2 ablation, and by the short time-scale of gene expression analyses. It mostly comprises upregulated genes, with nine of them being clearly associated with cell stress and inflammation: these encode the transcription factors Fos, Stat3, and Atf3, the complement molecules $\mathrm{C} 1 \mathrm{qa}, \mathrm{C} 1 \mathrm{qb}$, and C1qc, the TNF receptors Tnfrsfla and Tnfrsf12a, and the stress sensor Gadd45. The absence of OBR in the vicinity of all these genes and their shortdelayed induction identify them as the earliest secondary genetic events triggered by Otx2 ablation. Increased expression of the transcription factor Stat3 in Müller glia is a well-known protective retinal response to photoreceptor mutation or insults (Bramall et al., 2010). Upregulation of components of the complement cascade has also been documented in mouse models of inherited photoreceptor degeneration (Rattner and Nathans, 2005; Demos et al., 2008). These typical retinal responses clearly validate our model as a good means to identify the earliest signs of photoreceptor disease. Moreover, as the upregulated genes found here are strongly induced $4 \mathrm{~d}$ after the initial genetic event whereas apoptosis only starts after $20 \mathrm{~d}$, together these molecules likely represent the founding blocks on which the photoreceptor cell stress and apoptosis response are built. Targeting these molecules with chemical compounds that inhibit their activity might be of great interest for diminishing or abolishing photoreceptor degeneration. This could provide novel therapeutic tools for human late-onset retinal diseases, such as AMD. In addition, as most of these induced genes are widely expressed in neural tissues, they could be general markers of endangered neurons. Therefore, detection of their upregulation could help precocious clinical diagnosis of neurodegeneration.

\section{References}

Acampora D, Mazan S, Lallemand Y, Avantaggiato V, Maury M, Simeone A, Brûlet P (1995) Forebrain and midbrain regions are deleted in Otx $2^{-1-}$ mutants due to a defective anterior neuroectoderm specification during gastrulation. Development 121:3279-3290. Medline

Ajmal M, Khan MI, Neveling K, Khan YM, Ali SH, Ahmed W, Iqbal MS, Azam M, den Hollander AI, Collin RW, Qamar R, Cremers FP (2012) Novel mutations in RDH5 cause fundus albipunctatus in two consanguineous Pakistani families. Mol Vis 18:1558-1571. Medline

Bakrania P, Efthymiou M, Klein JC, Salt A, Bunyan DJ, Wyatt A, Ponting CP, Martin A, Williams S, Lindley V, Gilmore J, Restori M, Robson AG, Neveu MM, Holder GE, Collin JR, Robinson DO, Farndon P, Johansen-Berg H, Gerrelli D, et al. (2008) Mutations in BMP4 cause eye, brain, and digit developmental anomalies: overlap between the BMP4 and hedgehog signaling pathways. Am J Hum Genet 82:304-319. CrossRef Medline

Béby F, Housset M, Fossat N, Le Greneur C, Flamant F, Godement P, Lamonerie T (2010) Otx2 gene deletion in adult mouse retina induces rapid RPE dystrophy and slow photoreceptor degeneration. PLoS One 5:e11673. CrossRef Medline 
Bemelmans AP, Bonnel S, Houhou L, Dufour N, Nandrot E, Helmlinger D, Sarkis C, Abitbol M, Mallet J (2005) Retinal cell type expression specificity of HIV-1-derived gene transfer vectors upon subretinal injection in the adult rat: influence of pseudotyping and promoter. J Gene Med 7:1367-1374. CrossRef Medline

Beurdeley M, Spatazza J, Lee HH, Sugiyama S, Bernard C, Di Nardo AA, Hensch TK, Prochiantz A (2012) Otx2 binding to perineuronal nets persistently regulates plasticity in the mature visual cortex. J Neurosci 32:9429-9437. CrossRef Medline

Booij JC, ten Brink JB, Swagemakers SM, Verkerk AJ, Essing AH, van der Spek PJ, Bergen AA (2010) A new strategy to identify and annotate human RPE-specific gene expression. PLoS One 5:e9341. CrossRef Medline

Bramall AN, Wright AF, Jacobson SG, McInnes RR (2010) The genomic, biochemical, and cellular responses of the retina in inherited photoreceptor degenerations and prospects for the treatment of these disorders. Annu Rev Neurosci 33:441-472. CrossRef Medline

Calame M, Cachafeiro M, Philippe S, Schouwey K, Tekaya M, Wanner D, Sarkis C, Kostic C, Arsenijevic Y (2011) Retinal degeneration progression changes lentiviral vector cell targeting in the retina. PLoS One 6:e23782. CrossRef Medline

Cantos R, Cole LK, Acampora D, Simeone A, Wu DK (2000) Patterning of the mammalian cochlea. Proc Natl Acad Sci U S A 97:11707-11713. CrossRef Medline

Casey J, Kawaguchi R, Morrissey M, Sun H, McGettigan P, Nielsen JE, Conroy J, Regan R, Kenny E, Cormican P, Morris DW, Tormey P, Chróinín MN, Kennedy BN, Lynch S, Green A, Ennis S (2011) First implication of STRA6 mutations in isolated anophthalmia, microphthalmia, and coloboma: a new dimension to the STRA6 phenotype. Hum Mutat 32: 1417-1426. CrossRef Medline

Chatelain G, Fossat N, Brun G, Lamonerie T (2006) Molecular dissection reveals decreased activity and not dominant negative effect in human OTX2 mutants. J Mol Med 84:604-615. CrossRef Medline

Chau KY, Chen S, Zack DJ, Ono SJ (2000) Functional domains of the conerod homeobox (CRX) transcription factor. J Biol Chem 275:3726437270. CrossRef Medline

Chowers I, Wong R, Dentchev T, Farkas RH, Iacovelli J, Gunatilaka TL, Medeiros NE, Presley JB, Campochiaro PA, Curcio CA, Dunaief JL, Zack DJ (2006) The iron carrier transferrin is upregulated in retinas from patients with age-related macular degeneration. Invest Ophthalmol Vis Sci 47:2135-2140. CrossRef Medline

Demos C, Bandyopadhyay M, Rohrer B (2008) Identification of candidate genes for human retinal degeneration loci using differentially expressed genes from mouse photoreceptor dystrophy models. Mol Vis 14:16391649. Medline

Dhingra A, Sulaiman P, Xu Y, Fina ME, Veh RW, Vardi N (2008) Probing neurochemical structure and function of retinal ON bipolar cells with a transgenic mouse. J Comp Neurol 510:484-496. CrossRef Medline

Ettaiche M, Heurteaux C, Blondeau N, Borsotto M, Tinel N, Lazdunski M (2001) ATP-sensitive potassium channels (K(ATP)) in retina: a key role for delayed ischemic tolerance. Brain Res 890:118-129. CrossRef Medline

Feng J, Liu T, Qin B, Zhang Y, Liu XS (2012) Identifying ChIP-seq enrichment using MACS. Nat Protoc 7:1728-1740. CrossRef Medline

Fletcher EL, Jobling AI, Vessey KA, Luu C, Guymer RH, Baird PN (2011) Animal models of retinal disease. Prog Mol Biol Transl Sci 100:211-286. CrossRef Medline

Fong SL, Fong WB (1999) Elements regulating the transcription of human interstitial retinoid-binding protein (IRBP) gene in cultured retinoblastoma cells. Curr Eye Res 18:283-291. CrossRef Medline

Fossat N, Chatelain G, Brun G, Lamonerie T (2006) Temporal and spatial delineation of mouse Otx2 functions by conditional self-knockout. EMBO Rep 7:824-830. CrossRef Medline

Fossat N, Le Greneur C, Béby F, Vincent S, Godement P, Chatelain G, Lamonerie T (2007) A new GFP-tagged line reveals unexpected Otx2 protein localization in retinal photoreceptors. BMC Dev Biol 7:122. CrossRef Medline

Gentleman RC, Carey VJ, Bates DM, Bolstad B, Dettling M, Dudoit S, Ellis B, Gautier L, Ge Y, Gentry J, Hornik K, Hothorn T, Huber W, Iacus S, Irizarry R, Leisch F, Li C, Maechler M, Rossini AJ, Sawitzki G, et al. (2004) Bioconductor: open software development for computational biology and bioinformatics. Genome Biol 5:R80. CrossRef Medline

Gherzi R, Briata P, Boncinelli E, Ponassi M, Querzè G, Viti F, Corte G, Zardi L (1997) The human homeodomain protein OTX2 binds to the human
tenascin-C promoter and trans-represses its activity in transfected cells. DNA Cell Biol 16:559-567. CrossRef Medline

Gorbenko Del Blanco D, Romero CJ, Diaczok D, de Graaff LC, Radovick S, Hokken-Koelega AC (2012) A novel OTX2 mutation in a patient with combined pituitary hormone deficiency, pituitary malformation, and an underdeveloped left optic nerve. Eur J Endocrinol 167:441-452. CrossRef Medline

Hanitzsch R, Lichtenberger T (1997) Two neuronal retinal components of the electroretinogram c-wave. Doc Ophthalmol 94:275-285. CrossRef Medline

Kobi D, Steunou AL, Dembélé D, Legras S, Larue L, Nieto L, Davidson I (2010) Genome-wide analysis of POU3F2/BRN2 promoter occupancy in human melanoma cells reveals Kitl as a novel regulated target gene. Pigment Cell Melanoma Res 23:404-418. CrossRef Medline

Koike C, Nishida A, Ueno S, Saito H, Sanuki R, Sato S, Furukawa A, Aizawa S, Matsuo I, Suzuki N, Kondo M, Furukawa T (2007) Functional roles of Otx2 transcription factor in postnatal mouse retinal development. Mol Cell Biol 27:8318-8329. CrossRef Medline

Kostic C, Crippa SV, Pignat V, Bemelmans AP, Samardzija M, Grimm C, Wenzel A, Arsenijevic Y (2011) Gene therapy regenerates protein expression in cone photoreceptors in Rpe65(R91W/R91W) mice. PLoS One 6:e16588. CrossRef Medline

Liao JL, Yu J, Huang K, Hu J, Diemer T, Ma Z, Dvash T, Yang XJ, Travis GH, Williams DS, Bok D, Fan G (2010) Molecular signature of primary retinal pigment epithelium and stem-cell-derived RPE cells. Hum Mol Genet 19:4229-4238. CrossRef Medline

Machanick P, Bailey TL (2011) MEME-ChIP: motif analysis of large DNA datasets. Bioinformatics 27:1696-1697. CrossRef Medline

Martinez-Morales JR, Signore M, Acampora D, Simeone A, Bovolenta P (2001) Otx genes are required for tissue specification in the developing eye. Development 128:2019-2030. Medline

Martínez-Morales JR, Dolez V, Rodrigo I, Zaccarini R, Leconte L, Bovolenta P, Saule S (2003) OTX2 activates the molecular network underlying retina pigment epithelium differentiation. J Biol Chem 278:21721-21731. CrossRef Medline

Masuda T, Esumi N (2010) SOX9, through interaction with microphthalmiaassociated transcription factor (MITF) and OTX2, regulates BEST1 expression in the retinal pigment epithelium. J Biol Chem 285:26933-26944. CrossRef Medline

Neale BM, Fagerness J, Reynolds R, Sobrin L, Parker M, Raychaudhuri S, Tan PL, Oh EC, Merriam JE, Souied E, Bernstein PS, Li B, Frederick JM, Zhang K, Brantley MA Jr, Lee AY, Zack DJ, Campochiaro B, Campochiaro P, Ripke S, et al. (2010) Genome-wide association study of advanced agerelated macular degeneration identifies a role of the hepatic lipase gene (LIPC). Proc Natl Acad Sci U S A 107:7395-7400. CrossRef Medline

Nishida A, Furukawa A, Koike C, Tano Y, Aizawa S, Matsuo I, Furukawa T (2003) Otx2 homeobox gene controls retinal photoreceptor cell fate and pineal gland development. Nat Neurosci 6:1255-1263. CrossRef Medline

Orr A, Dubé MP, Zenteno JC, Jiang H, Asselin G, Evans SC, Caqueret A, Lakosha H, Letourneau L, Marcadier J, Matsuoka M, Macgillivray C, Nightingale M, Papillon-Cavanagh S, Perry S, Provost S, Ludman M, Guernsey DL, Samuels ME (2011) Mutations in a novel serine protease PRSS56 in families with nanophthalmos. Mol Vis 17:1850-1861. Medline

Pacione LR, Szego MJ, Ikeda S, Nishina PM, McInnes RR (2003) Progress toward understanding the genetic and biochemical mechanisms of inherited photoreceptor degenerations. Annu Rev Neurosci 26:657-700. CrossRef Medline

Pang J, Cheng M, Haire SE, Barker E, Planelles V, Blanks JC (2006) Efficiency of lentiviral transduction during development in normal and $\mathrm{rd}$ mice. Mol Vis 12:756-767. Medline

Pauer GJ, Sturgill GM, Peachey NS, Hagstrom SA (2010) Protective effect of paraoxonase 1 gene variant Gln192Arg in age-related macular degeneration. Am J Ophthalmol 149:513-522. CrossRef Medline

Puelles E, Acampora D, Lacroix E, Signore M, Annino A, Tuorto F, Filosa S, Corte G, Wurst W, Ang SL, Simeone A (2003) Otx dose-dependent integrated control of antero-posterior and dorso-ventral patterning of midbrain. Nat Neurosci 6:453-460. Medline

Ragge NK, Brown AG, Poloschek CM, Lorenz B, Henderson RA, Clarke MP, Russell-Eggitt I, Fielder A, Gerrelli D, Martinez-Barbera JP, Ruddle P, Hurst J, Collin JR, Salt A, Cooper ST, Thompson PJ, Sisodiya SM, Williamson KA, Fitzpatrick DR, van Heyningen V, et al. (2005) Heterozy- 
gous mutations of OTX2 cause severe ocular malformations. Am J Hum Genet 76:1008-1022. CrossRef Medline

Rattner A, Nathans J (2005) The genomic response to retinal disease and injury: evidence for endothelin signaling from photoreceptors to glia. J Neurosci 25:4540-4549. CrossRef Medline

Ray K, Sengupta M (2010) Novel human pathological mutations. Gene symbol: OCA2. Disease: albinism, oculocutaneous II. Hum Genet 127: 487-488. Medline

RetNet (2013) Retinal Information Network. https://sph.uth.edu/retnet/.

Saeed AI, Bhagabati NK, Braisted JC, Liang W, Sharov V, Howe EA, Li J, Thiagarajan M, White JA, Quackenbush J (2006) TM4 microarray software suite. Methods Enzymol 411:134-193. CrossRef Medline

Sato M, Oshika T, Kaji Y, Nose H (2004) A novel homozygous Gly107Arg mutation in the RDH5 gene in a Japanese patient with fundus albipunctatus with sectorial retinitis pigmentosa. Ophthalmic Res 36:43-50. CrossRef Medline

Sato S, Inoue T, Terada K, Matsuo I, Aizawa S, Tano Y, Fujikado T, Furukawa $\mathrm{T}$ (2007) Dkk3-Cre BAC transgenic mouse line: a tool for highly efficient gene deletion in retinal progenitor cells. Genesis 45:502-507. CrossRef Medline

Sergouniotis PI, Sohn EH, Li Z, McBain VA, Wright GA, Moore AT, Robson AG, Holder GE, Webster AR (2011) Phenotypic variability in RDH5 retinopathy (Fundus Albipunctatus). Ophthalmology 118:1661-1670. CrossRef Medline

Shin H, Liu T, Manrai AK, Liu XS (2009) CEAS: cis-regulatory element annotation system. Bioinformatics 25:2605-2606. CrossRef Medline

Siegert S, Cabuy E, Scherf BG, Kohler H, Panda S, Le YZ, Fehling HJ, Gaidatzis D, Stadler MB, Roska B (2012) Transcriptional code and disease map for adult retinal cell types. Nat Neurosci 15:487-495. CrossRef Medline

Slavotinek AM (2011) Eye development genes and known syndromes. Mol Genet Metab 104:448-456. CrossRef Medline

Steventon B, Mayor R, Streit A (2012) Mutual repression between Gbx2 and Otx2 in sensory placodes reveals a general mechanism for ectodermal patterning. Dev Biol 367:55-65. CrossRef Medline
Swarup G, Nagabhushana A (2010) Optineurin, a multifunctional protein involved in glaucoma, amyotrophic lateral sclerosis and antiviral signalling. J Biosci 35:501-505. CrossRef Medline

Takeda K, Yokoyama S, Yasumoto Ki, Saito H, Udono T, Takahashi K, Shibahara S (2003) OTX2 regulates expression of DOPAchrome tautomerase in human retinal pigment epithelium. Biochem Biophys Res Commun 300:908-914. CrossRef Medline

Ting AY, Lee TK, MacDonald IM (2009) Genetics of age-related macular degeneration. Curr Opin Ophthalmol 20:369-376. CrossRef Medline

Wright AF, Chakarova CF, Abd El-Aziz MM, Bhattacharya SS (2010) Photoreceptor degeneration: genetic and mechanistic dissection of a complex trait. Nat Rev Genet 11:273-284. CrossRef Medline

Wysokinski D, Szaflik J, Sklodowska A, Kolodziejska U, Dorecka M, Romaniuk D, Wozniak K, Blasiak J, Szaflik JP (2011) The A allele of the $-576 \mathrm{G}>$ A polymorphism of the transferrin gene is associated with the increased risk of age-related macular degeneration in smokers. Tohoku J Exp Med 223:253-261. CrossRef Medline

Young RW, Bok D (1969) Participation of the retinal pigment epithelium in the rod outer segment renewal process. J Cell Biol 42:392-403. CrossRef Medline

Yu Y, Bhangale TR, Fagerness J, Ripke S, Thorleifsson G, Tan PL, Souied EH, Richardson AJ, Merriam JE, Buitendijk GH, Reynolds R, Raychaudhuri S, Chin KA, Sobrin L, Evangelou E, Lee PH, Lee AY, Leveziel N, Zack DJ, Campochiaro B, et al. (2011) Common variants near FRK/COL10A1 and VEGFA are associated with advanced age-related macular degeneration. Hum Mol Genet 20:3699-3709. CrossRef Medline

Zhang KH, Li Z, Lei J, Pang T, Xu B, Jiang WY, Li HY (2011) Oculocutaneous albinism type 3 (OCA3): analysis of two novel mutations in TYRP1 gene in two Chinese patients. Cell Biochem Biophys 61:523529. CrossRef Medline

Zindler E, Zipp F (2010) Neuronal injury in chronic CNS inflammation. Best Pract Res Clin Anaesthesiol 24:551-562. CrossRef Medline 